\title{
PERLINDUNGAN HUKUM BANGUNAN CAGAR BUDAYA DI KOTA MALANG SEBAGAI WARISAN BUDAYA BANGSA
}

\author{
Sulthon Miladiyanto ${ }^{(1)}$,Ririen Ambarsari ${ }^{(2)}$,Anindya Bidasari( ${ }^{(3)}$ \\ sulthon_miladiyanto@unikama.ac.id(1), ririen_ambarsari@unikama.ac.id ${ }^{(2)}$, \\ anindya_bidasari@gmail.com ${ }^{(3)}$,
}

Fakultas Hukum Universitas Kanjuruhan Malang

\begin{abstract}
Cultural heritage is a nation's assets that have very valuable values, in which they are able to tell many historical events of the struggle as learning material to build the nation's character and have high artistic values that are able to inspire and have economic value for the prosperity of society. Therefore, it needs a planned and systematic effort to provide protection to cultural heritage. The constitution is the basis for the legislation promulgated by both central and regional governments including Law Number 11 of 2010 concerning Cultural Heritage, East Java Governor Regulation Number 66 of 2015 concerning Preservation of Cultural Heritage in East Java Province, and Malang City Regulation Number 1 of 2018 concerning Cultural Heritage and other relevant laws and regulations. Malang City Government through several businesses that retain historical heritage buildings: 1) Utilization of the utilization of Cultural Heritage for the benefit of the people's welfare while maintaining its sustainability, 2) Revitalization is a development activity aimed at regrowing the important values of Cultural Heritage by adjusting the function of a new space that is not in conflict with the principles of preservation and cultural values of the community, and 3) Adaptation is an effort to develop a Cultural Heritage for activities that are more in line with the needs of the present by making limited changes that will not result in deterioration in its importance or damage to parts that have important value.
\end{abstract}

Keywords: legal protection, cultural heritage building, Malang city

\section{ABSTRAK}

Warisan budaya adalah aset bangsa yang memiliki nilai-nilai yang sangat berharga, di mana mereka mampu menceritakan banyak peristiwa bersejarah perjuangan sebagai bahan belajar untuk membangun karakter bangsa dan memiliki nilai seni tinggi yang mampu menginspirasi dan memiliki nilai ekonomi untuk kesejahteraan masyarakat. Oleh karena itu, diperlukan upaya yang terencana dan sistematis untuk memberikan perlindungan terhadap warisan budaya. Konstitusi merupakan dasar bagi legislasi yang dikeluarkan oleh pemerintah pusat dan daerah termasuk Undang-Undang Nomor 11 tahun 2010 tentang Warisan Budaya, Peraturan Gubernur Jawa Timur Nomor 66 Tahun 2015 tentang Pelestarian Warisan Budaya di Provinsi Jawa Timur, dan Peraturan Kota Malang Nomor 12018 tentang Warisan Budaya dan undang-undang dan peraturan terkait lainnya. Pemerintah Kota Malang melalui beberapa bisnis yang mempertahankan bangunan peninggalan sejarah: 1) Pemanfaatan pemanfaatan Warisan Budaya untuk kepentingan kesejahteraan rakyat dengan tetap menjaga keberlanjutannya, 2) Revitalisasi adalah kegiatan pembangunan yang bertujuan menumbuhkan kembali nilai-nilai penting Warisan Budaya oleh menyesuaikan fungsi ruang baru yang tidak bertentangan dengan prinsip 
pelestarian dan nilai-nilai budaya masyarakat, dan 3) Adaptasi adalah upaya untuk mengembangkan Warisan Budaya untuk kegiatan yang lebih sesuai dengan kebutuhan masa kini oleh membuat perubahan terbatas yang tidak akan mengakibatkan kerusakan pada kepentingannya atau kerusakan pada bagian-bagian yang memiliki nilai penting.

Kata Kunci: perlindungan hukum, bangunan cagar budaya, kota malang,

\section{PENDAHULUAN}

Peradaban suatu bangsa dapat dinilai dari warisan budaya yang ditinggalkannya. Kebudayaan dengan kata dasar budaya berasal dari bahasa sansekerta "buddhayah", yaitu bentuk jamak dari buddhi yang berarti "budi" atau "akal". Jadi definisi budaya sebagai "daya budi" yang berupa cipta, karsa dan rasa, sedangkan kebudayaan adalah hasil dari cipta, karsa dan rasa itu. ${ }^{1}$ Semakin megah dan beragam budaya yang ditinggalkannya maka dapat dikatakan bahwa budaya bangsa tersebut dianggap maju.

Warisan budaya yang mumpuni ini berunsur budaya etnik, adiluhung, sakral, kreatif, sekaligus bernilai jual. ${ }^{2}$ Oleh karena itu perlu adanya suatu perlindungan Hak Cipta terhadap kekayaan intelektual yang lahir dari keanekaragaman kreatifitas manusia di bidang seni termasuk karya ciptaan yang bernilai seni tinggi pada bangunan cagar budaya tersebut.

Semangat perlindungan terhadap cagar budaya dapat terlihat dengan upanya pemerintah mengeluarkan peraturan perundangan yang berkaitan dengan cagar budaya diantaranya Undang-undang Nomor 11 Tahun 2010 tentang Cagar Budaya, dalam Pasal 1 ayat (1) Cagar Budaya adalah warisan budaya bersifat kebendaan berupa Benda Cagar Budaya, Bangunan Cagar Budaya, Struktur Cagar Budaya, Situs Cagar Budaya, dan Kawasan Cagar Budaya di darat dan/atau di air yang perlu dilestarikan keberadaannya karena memiliki nilai penting bagi sejarah, ilmu pengetahuan, pendidikan, agama, dan/atau kebudayaan melalui proses penetapan. Juga dapat dikaitkan dengan Undang-Undang Hak Cipta yang dikeluarkan dalam rangka untuk

${ }^{1}$ Koentjaraningrat,2012, Pengantar IImu Antropologi, Radar Jaya Offset, Jakarta, h. 184.

2Sardjono, Agus, 2007, Bagaimana Melindungi Kekayaan Warisan Budaya Sebagai Kekayaan Intelektual Bangsa. Melalui makalahnya pada Seminar Pekan Produk Budaya Indonesia,h.5. 
mendorong dan melindungi pencipta dan hasil karya ciptaannya. Dengan demikian diharapkan hasil kebudayaan di bidang karya ilmu, seni dan sastra dapat dilindungi secara yuridis. Berdasarkan Undang-Undang Hak Cipta Nomor 28 tahun 2014 (selanjutnya disebut dengan UUHC 2014) telah diatur di dalam Pasal 40 ayat (1) huruf $h$ bahwa ciptaan bangunan merupakan obyek ciptaan yang dilindungi oleh UU Hak Cipta yaitu bidang karya arsitektur antara lain meliputi seni gambar bangunan, seni gambar miniatur, dan seni gambar maket bangunan. Dalam penjelasannya Yang dimaksud dengan "karya arsitektur" antara lain, wujud fisik bangunan, penataan letak bangunan, gambar rancangan bangunan, gambar teknis bangunan, dan model atau maket bangunan.

Memang sungguh ironis kenyataan yang terjadi sekarang, banyak bangunan cagar budaya di Kota Malang yang dialihfungsikan bersama kemungkinan dilakukannya pembongkaran dengan pembangunan fasilitas baru atau berbagai alasan tertentu seperti pertimbangan pelaksanaan teknis yang tidak tepat sebagai alasan pembenarnya. Contohnya Alun-alun Malang sebagai pusat kegiatan sosial bagi masyarakat Malang dan daerah yang penuh dengan peninggalansejarah, seharusnya bangunan bersejarah yang ada tetap dipertahankan. Tapi kenyataannya banyak yang sudah berubah, mulai dari penjara wanita yang berubah menjadi Kompleks Ramayana dan Gedung Societeit Concordia telah berubah menjadi Pertokoan Sarinah. Di kawasan jalan Kawi juga terdapat perubahan bentuk bangunan bersejarah, yakni sebuah gedung pertemuan yang bernama Gedung Kartini. Saat ini gedung tersebut sudah menjadi sentra perdagangan dan jasa yaitu Mal Olympic Garden (MOG). Sedangkan di daerah balai kota terdapat Gedung DPRD yang dirobohkan dan diubah menjadi bangunan baru yang bentuknya juga berubah dari asalnya.

Berdasarkan uraian di atas, terdapat beberapa permasalahan yaitu: 1) Apakah pengalihfungsian bangunan cagar budaya di kota Malang melanggar Undang-Undang Nomor 28 Tahun 2014 tentang Hak Cipta dan Undang-Undang Nomor 11 tahun 2010 tentang Cagar Budaya? 2) Bagaimanakah peran pemerintah kota dalam memberikan perlindungan terhadap bangunan cagar budaya di kota Malang? 


\section{Hasil Penelitian dan Pembahasan}

Pengaturan cagar budaya di Indonesia secara mendasar dapat ditemukan pada Pasal 32 ayat (1) Undang-Undang Dasar Negara Republik Indonesia Tahun 1945 yang mengamanatkan bahwa: "Negara memajukan kebudayaan nasional Indonesia di tengah peradaban dunia dengan menjamin kebebasan masyarakat dalam memelihara dan mengembangkan nilai-nilai budayanya"

Pemerintah Indonesia berkewajiban "melaksanakan kebijakan memajukan kebudayaan secara utuh untuk sebesar-besarnya kemakmuran rakyat". Rumusan ini menjadi pedoman dalam menyusun Pasal yang berisi perintah, larangan, anjuran, pengaturan, dan hukuman berkenaan dengan budaya yang berpihak kepada masyarakat.

Cagar budaya merupakan kekayaan budaya bangsa yang penting artinya bagi pemahaman, pengembangan sejarah, ilmu pengetahuan dan kebudayaan, sehingga perlu dilindungi dan dilestarikan sebagai bekal pembangunan jatidiri bangsa untuk kepentingan nasional.Menjaga kelestarian benda cagar budaya diperlukan langkah pengaturan bagi penguasaan, pemilik, penemuan, pencarian, perlindungan, pemeliharaan, pengelolaan, pemanfaatan, dan pengawasan cagar budaya.

Pengaturan cagar budaya yang pernah berlaku di Indonesia dimulai dalam Monumenten Ordonnantie Nomor 19 Tahun 1931 (Staatsblad Tahun 1931 Nomor 238), sebagaimana telah diubah dengan Monumenten Ordonnantie Nomor 21 Tahun 1934 (Staatsblad Tahun 1934 Nomor 515) dan dalam masa kemerdekaan cagar budaya diatur dalam UU Nomor 5 tahun 1992 tentang benda cagar budaya yang kemudian dirubah lagi dengan UU nomor 11 tahun 2010 tentang cagar budaya, yang prinsipnya semua peraturan tersebut sebagai upaya perlindungan dan pemeliharaan demi pelestarian cagar budaya.

Secara umum di undang-undang yang pernah ada, mengkategorikan jenis cagar budaya yang dapat dilindungi keberadaannya adalah warisan budaya bersifat kebendaan berupa Benda Cagar Budaya, Bangunan Cagar Budaya, Struktur Cagar Budaya, Situs Cagar Budaya, dan Kawasan Cagar Budaya di darat dan/atau di air yang perlu dilestarikan keberadaannya karena memiliki nilai penting bagi sejarah, ilmu pengetahuan, pendidikan, agama, dan/atau kebudayaan melalui proses 
penetapan. $^{3}$

UNESCO mendefinisikan kawasan bersejarah adalah sebagai berikut: 4

"Group of buildings: Group of separate or connected buildings, which because of their architecture, their homogeneity ar their place in landscape, are of outstanding universal value from the point of view of history, art or science"

Undang-undang yang pernah ada juga secara umum telah menetapkan Kriteria cagar budaya yaitu: ${ }^{5} a$ ) Berusia 50 (lima puluh) tahun atau lebih. b) Mewakili masa gaya paling singkat berusia 50 (lima puluh) tahun; c) Memiliki arti khusus bagi sejarah, ilmu pengetahuan,pendidikan, agama, dan/atau kebudayaan; dan d) Memiliki nilai budaya bagi penguatan kepribadian bangsa.

Berdasar latar belakang Undang-undang Nomor 5 tahun 1992 tentang cagar budaya dianggap memiliki kelemahan diantaranya a) pembatasan peran pelindungan benda cagar budaya oleh pemiliknya; b) penjualan benda cagar budaya dianggap sebagai pelanggaran hukum; c) tidak ada keuntungan langsung bagi pemilik benda cagar budaya apabila mereka aktif melakukan pelestarian; atau d) kesan masyarakat yang paling penting untuk dicatat adalah bahwa Undang-Undang Nomor 5 Tahun 1992 tentang Benda Cagar Budaya ialah secara keseluruhan sangat berorientasi pada kewenangan Pemerintah Pusat. Peran Pemerintah Daerah dan masyarakat sebagai pemilik benda cagar budaya sangat sedikit disinggung di dalamnya, sifat larangan yang konservatif dalam hal tertentu seperti untuk mempertahakan eksistensi benda cagar budaya dianggap baik, akan tetapi pada sisi yang lain seperti kewajiban Pemerintah Pusat sendiri kepada masyarakat nyaris tidak diatur secara rinci di dalamnya.

Upaya penguatan kewenangan pemerintah daerah terdorong dengan adanya Ketetapan MPR RI Nomor XV/MPR/1998 tentang Penyelenggaraan Otonomi Daerah, Pengaturan, pembagian, dan Budaya

${ }^{3}$ Pasal 1 ayat 1 Undang-undang Nomor 11 Tahun 2010 tentang Cagar

${ }^{4}$ UNESCO,1987, dalam "Convention Concerning the Protection of the World Cultural and Natural Heritage".

${ }^{5}$ Pasal 5 Undang-undang Nomor 11 Tahun 2010 tentang Cagar Budaya 
Pemanfaatan Sumber Daya Nasional yg Berkeadilan, serta perimbangan keuangan Pusat dan Daerah dalam Kerangka NKRI, Ketetapan MPR RI Nomor IV/MPR/2000 tentang Rekomendasi Kebijakan dalam Penyelenggaraan Otonomi Daerah, dan UU No. 32 Tahun 2004 tentang Pemerintahan Daerah, secara prinsip mendorong dari sentralisasi menuju ke desentralisasi

Pemberian kewenangan yang cukup besar kepada Pemerintah Daerah telah termuat dalam Undang-Undang Nomor 11 Tahun 2010 Tentang Cagar Budaya. Undang-undang tersebut menyebutkan adanya 16 kewenangan, antara lain sebagai berikut: ${ }^{6}$ 1) Menetapkan etika Pelestarian Cagar Budaya; 2) Mengoordinasikan Pelestarian Cagar Budaya secara lintas sektor dan wilayah; 3) Menghimpun data Cagar Budaya; 4) Menetapkan peringkat Cagar Budaya; 5) Menetapkan dan mencabut status Cagar Budaya; 6) Membuat peraturan Pengelolaan Cagar Budaya; 7) Menyelenggarakan kerja sama Pelestarian Cagar Budaya; 8) Melakukan penyidikan kasus pelanggaran hukum; 8) Mengelola Kawasan Cagar Budaya; 9) Mendirikan dan membubarkan unit pelaksana teknis bidang pelestarian, penelitian, dan museum; 10) Mengembangkan kebijakan sumber daya manusia di bidang kepurbakalaan; 11) Memberikan penghargaan kepada setiap orang yang telah melakukan Pelestarian Cagar Budaya; 12) Memindahkan dan/atau menyimpan Cagar Budaya untuk kepentingan pengamanan; 13) Melakukan pengelompokan Cagar Budaya berdasarkan kepentingannya menjadi peringkat nasional, peringkat provinsi, dan peringkat kabupaten/kota; 14) Menetapkan batas situs dan kawasan; dan 15) Menghentikan proses pemanfaatan ruang atau proses pembangunan yang dapat menyebabkan rusak, hilang, atau musnahnya Cagar Budaya, baik seluruh maupun bagian-bagiannya.

Kewenangan yang sama juga diberikan kepada Pemerintah Pusat, kecuali 5 (lima) kewenangan yang bersifat pengaturan di tingkat nasional, yaitu: 1) Menyusun dan menetapkan Rencana Induk Pelestarian Cagar Budaya; 2) Melakukan pelestarian Cagar Budaya yang ada di daerah perbatasan dengan negara tetangga atau yang berada di luar negeri; 3) Menetapkan Benda Cagar Budaya, Bangunan Cagar Budaya, Struktur Cagar Budaya, Situs Cagar Budaya, dan/atau Kawasan Cagar Budaya

${ }^{6}$ Pasal 96 Undang-undang Nomor 11 Tahun 2010 tentang Cagar budaya 
sebagai Cagar Budaya Nasional; 4) Mengusulkan Cagar Budaya Nasional sebagai warisan dunia atau Cagar Budaya bersifat internasional; dan 5) Menetapkan norma, standar, prosedur, dan kriteria Pelestarian Cagar Budaya.

Selain itu, Unit Pelaksana Teknis yang merupakan kepanjangan tangan dari Pemerintah Pusat seperti Balai Pelestraian Peninggalan Purbakala (BP3), Balai Pelestarian Sejarah dan Nilai Tradisional, atau Balai Arkeologi tidak termasuk yang diserahkan kewenangannya kepada Pemerintah Daerah. Namun Undang-Undang Cagar Budaya memberi peluang bagi Pemerintah Provinsi atau Pemerintah Kabupaten/Kota untuk mendirikan atau membubarkan Unit Pelaksana Teknis Daerah (UPTD) menurut kebutuhan. Daerah bahkan diberi tugas untuk menetapkan, menghapus, atau melakukan peringkat kepentingan terhadap cagar budaya yang berada di wilayah administrasinya masing-masing.

Mendapat lampu hijau, Pemerintah daerah berupaya mengeluarkan peraturan daerah yang memiliki fungsi perlindungan yang lebih komprehensif terhadap cagar budaya di wilayahnya masing-masing, diantaranya Pemerintah Provinsi Jawa Timur mengeluarkan peraturan daerah Provinsi Jawa Timur yaitu Peraturan Gubernur Jawa Timur Nomor 66 Tahun 2015 Tentang Pelestarian Cagar Budaya Provinsi Jawa Timur dan dilanjutkan Kota Malang mengeluarkan Peraturan Daerah Kota Malang yaitu Peraturan Walikota Malang Nomor 1 Tahun 2018 Tentang Cagar Budaya.

Peraturan perundangan cagar budaya di berbagai tingkatan secara umum telah mengatur alih fungsi dalam pemanfaatan cagar budaya yang diperbolehkan dengan tujuan utama meningkatkan kesejahteraan rakyat dengan tetap memperhatikan dan melindungi cagar budaya. Sebagaimana dalam Undang-undang Nomor 11 Tahun 2010 tentang Cagar Budaya Pasal 81 sampai Pasal 93 dengan substansi pemanfaatan alih fungsi cagar budaya terlebih dahulu diawali dengan adanya permohonan dari pihakpihak yang berkeinginan kepada pemerintah daerah dilanjutkan adanya kajian penelitian untuk mengetahui resiko pemanfaatan dan pengalihfungian cagar budaya tersebut kemudian jika pemerintah menganggap layak diberi ijin pemanfaatan maupun alih fungsi cagar budaya tersebut maka akan diterbitkan ijin, tidak hanya itu saja pemerintah 
daerah juga dibebani untuk mempromosikan cagar budaya tersebut.

Cagar budaya merupakan suatu hasil kemampuan kreatifitas yang sangat dekat dengan hak cipta, yang didalam hak cipta memiliki beberapa hak, salah satu aspek khusus yaitu Hak Ekonomi (economic right).Hak ekonomi adalah hak ekslusif pencipta atau pemegang hak cipta untuk mendapat manfaat ekonomi atas ciptaan 7 I. Dikatakan Hak ekonomi karena hak cipta yang dapat dinilai dengan uang. hak ekonomi tersebut berupa keuntungan sejumlah uang yang diperoleh karena penggunaan sendiri hak cipta, atau karena penggunaan oleh pihak lain berdasarkan lisensi. Hak ekonomi itu diperhitungkan karena hak cipta dapat digunakan oleh pihak lain dalam perindustrian atau perdagangan yang mendatangkan keuntungan. dengan kata lain, hak cipta adalah objek perdagangan.

Undang-Undang Nomor 12 tahun 2011 tentang Cagar Budaya, sejalan dengan Undang-Undang Nomor 28 tahun 2014 tentang Hak Cipta dengan perinsip hak ekonomi. Sebuah cagar budaya dapat diambil manfaatnya salah satunya adalah dengan menjadikan cagar budaya menjadi objek memperoleh keuntungan oleh pemiliknya atau pemegang hak cipta tersebut. Dalam hal ini pemanfaatan hak ekonomi ini dapat menunjang perekonomian pemilik ciptaan dan digunakan untuk perawatan ciptaan.

Hak Moral, adalah hak yang melindungi kepentingan pribadi atau reputasi pencipta atau penemu. Hak moral melekat pada pribadi pencipta/ pengarang untuk dapat mencegah perubahan atas karyanya dan untuk tetap disebut sebagai pencipta karya tersebut. ${ }^{8}$ Apabila Hak Cipta dialihkan kepada pihak lain, maka Hak moral tidak dapat dipisahkan dari pencipta atau penemu karena bersifat pribadi dan kekal. Sifat pribadi menunjukan ciri khas yang berkenaan dengan nama baik, kemampuan, integritas yang hanya dimiliki oleh pencipta. Kekal artinya melekat pada pencipta sela hidup bahkan sampai meninggal dunia. Termasuk dalam Hak Moral adalah sebagai berikut: 1) Hak untuk menuntut kepada pemegang Hak Cipta atau Paten sehingga nama pencipta tetap dicantumkan pada Ciptaan atau penemuannya. 2) Hak untuk tidak melakukan perubahan pada ciptaan atau

${ }^{7}$ Pasal 8 Undang-Undang Nomor 28 Tahun 2014 tentang Hak Cipta.

${ }^{8}$ Lindsey, Tim, Eddy Damian, Simon Butt, Tomi Suryo Utomo, 2006, Hak Kekayaan Intelektual Suatu Pengantar, PT Alumni, Bandung, h. 118. 
penemuan tanpa persetujuan pencipta, penemu, atau ahliwarisnya. 3) Hak pencipta untuk mengadakan perubahan pada ciptaan atau temuan sesuai dengan tuntutan perkembangan dan kepatutan dalam masyarakat.

Penerapan dalam rangka perlindungan cagar budaya untuk hak cipta yaitu yang pertama dengan tetap mencantumkan sejarah dari pendiri, pencipta atau pembuat cagar budaya tersebut, baik individu maupun kelompok atau perusahaan. Dalam hal ini benda cagar budaya di Malang sebagian besar pencipta atau pendiri adalah perusahaan Belanda di masa penjajahan. Kedua dengan menjaga keutuhan cagar budaya sesuai dengan aslinya, ketiga, jika benda cagar budaya tersebut membutuhkan pembenahan karena tuntutan usia dan dapat membahayakan sekitarnya maka pembenahannya tanpa meninggalkan sifat keasliannya dan dapat memberi manfaat kepada pemilik dan khalayak umum.

Secara umum dalam Undang-Undang Hak Cipta tidak mengatur secara pasti tentang pengalihan fungsi dari agar budaya yang dilindungan oleh Undang-Undang cagar Budaya tetap hanya melindungi hak dari pencipta benda cagar budaya tersebut, sedangkan keperuntukan dari barang ciptaan diserahkan kepada si pemilik sepanjang tidak melanggar hak ekonomi dan hak moral dari si pencipta.

Berdasarkan Undang-undang Nomor 11 Tahun 2010 tentang Cagar Budaya, bangunan cagar budaya adalah susunan binaan yang terbuat dari benda alam atau benda buatan manusia untuk memenuhi kebutuhan ruang berdinding dan/atau tidak berdinding, dan beratap.

Sedangkan pengertian warisan budaya menurut Young yang dikutip oleh Ni Made Mitha Mahastuti dalam Waradi adalah keseluruhan hasil budaya dari perilaku belajar atau berpola dari kelompok masyarakat tertentu yang diwarisi dari generasi sebelumnya yang kemudian diubah, dan dilanjutkan ke generasi berikutnya.Warisan budaya dapat berwujud tangible culture dimana warisan budaya berbentuk fisik, seperti bangunan gedung, monumen, buku, patung, artefak, intangible culture atau warisan budaya berbentuk non-fisik, seperti budaya, cerita rakyat, tradisi, adat, bahasa, pengetahuan, natural heritage atau warisan budaya berbentuk alami, seperti lingkungan alam termasuk flora dan fauna langka, keanekaragaman hayati, unsur geologi seperti mineralogi, geomorfologi, paleontologi. 
Upaya Mempertahankan Cagar Budaya Peninggalan Sejarah Berdasarkan Perda Kota Malang Nomor 1 tahun 2018 tentang Cagar Budaya, melalui beberapa usaha yang mempertahankan bangunan peninggalan sejarah: 1) Pemanfaatan yaitu pendayagunaan Cagar Budaya untuk kepentingan sebesar-besarnya kesejahteraan rakyat dengan tetap mempertahankan kelestariannya. 2) Revitalisasi yaitu kegiatan pengembangan yang ditujukan untuk menumbuhkan kembali nilai-nilai penting Cagar Budaya dengan penyesuaian fungsi ruang baru yang tidak bertentangan dengan prinsip pelestarian dan nilai budaya masyarakat. 3) Adaptasi yaitu upaya pengembangan Cagar Budaya untuk kegiatan yang lebih sesuai dengan kebutuhan masa kini dengan melakukan perubahan terbatas yang tidak akan mengakibatkan kemerosotan nilai pentingnya atau kerusakan pada bagian yang mempunyai nilai penting.

Lokasi penelitian ini adalah di kota Malang. Kota Malang (diucapkan [malan]) adalah sebuah kota yang terletak di Provinsi Jawa Timur, Indonesia, kota terbesar kedua di Jawa Timur setelah Surabaya, dan kota terbesar ke-12 di Indonesia. Kota ini didirikan pada masa Kerajaan Kanjuruhan dan terletak di dataran tinggi seluas 145,28 km2 yang terletak di tengah-tengah Kabupaten Malang. Bersama dengan Kota Batu dan Kabupaten Malang, Kota Malang merupakan bagian dari kesatuan wilayah yang dikenal dengan Malang Raya.Kota Malang menyimpan berbagai peninggalan bersejarah, mulai dari masa Kerajaan Kanjuruhan hingga Belanda. Peninggalan Belanda pada umumnya berupa bangunanbangunan kuno seperti Gereja Kayutangan yang berarsitektur gotik.

Berbekal Perda Kota Malang Nomor 1 Tahun 2018 Tentang Cagar Budaya, Walikota Malang dapat menetapkan benda/wilayah/situs/bangunan cagar budaya tingkat Kota, dalam hal ini Walikota Malang akan menetapkan 20 (dua puluh) objek Cagar Budaya Kota Malang, diantaranya: ${ }^{9}$ (1) Gedung Balai Kota Malang, (2) SMA Tugu, (3) Stasiun Kota Baru Malang, (4) Jembatan Spendid serta Kahuripan. (5) Gedung Bank Indonesia (BI), (6) Gereja Kayutangan, (7) Gereja Immanuel, (8) Masjid Jami. (9) Bangunan PKPN, (10) PLN, (11) Gereja Idjen, (12) Corjesu, (13) Klenteng Ang Eng Kiong. (14) Buk Gludug, (15) Rumah Dinas 
Walikota, (16) Tandon Air Betek Tlogomas, (17) Brandweer, (18) Hotel Pelangi, (19) Koleksi Museum Mpu Purwa, dan (20) Makam Gribig.

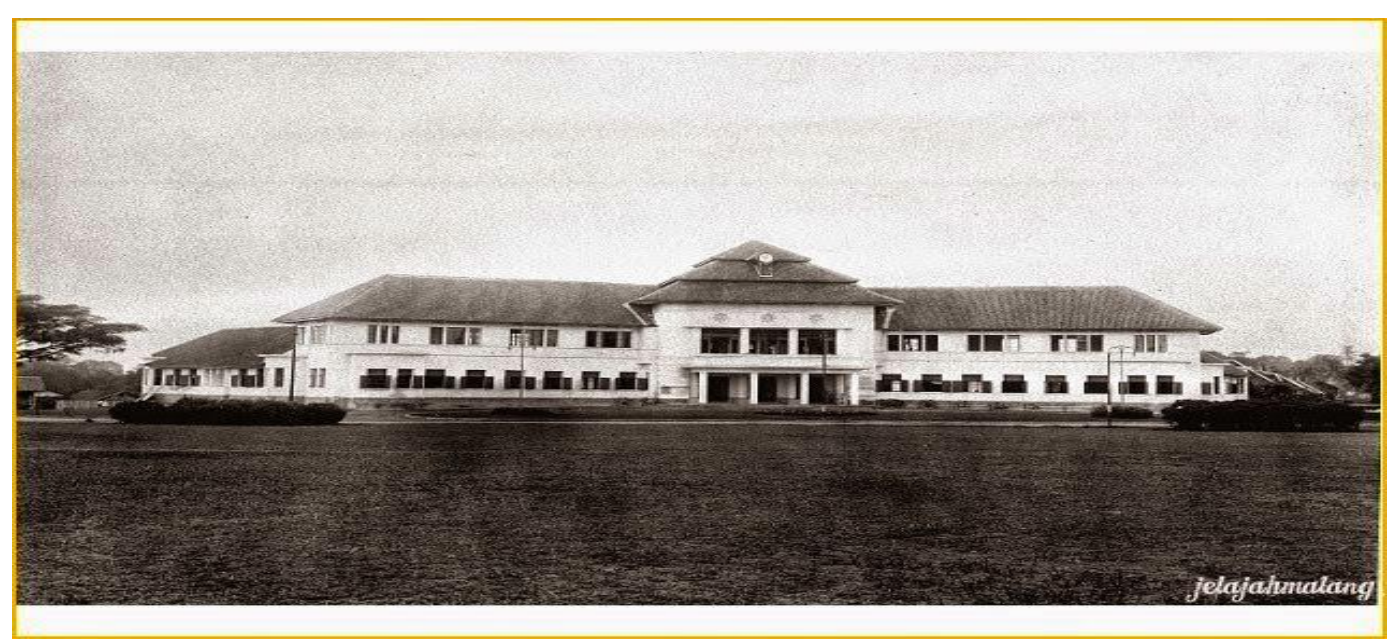

Gambar 1. Balai Kota Malang Tahun 1920

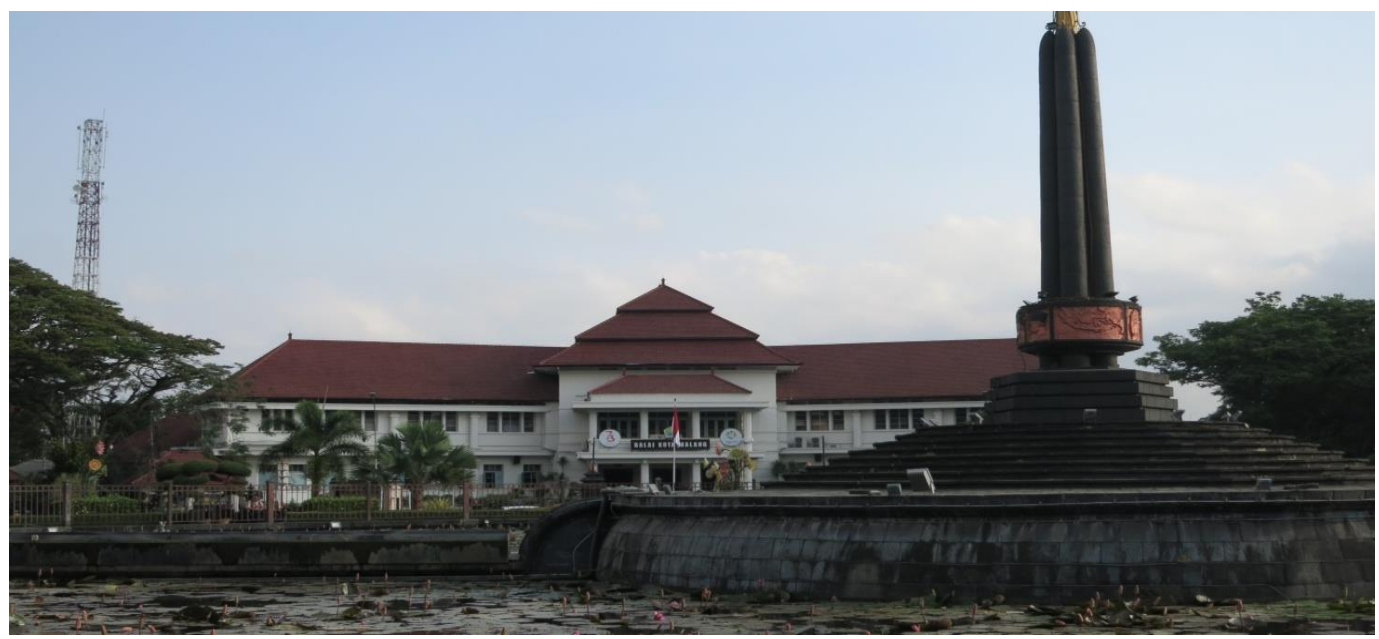

Gambar 2. Balai Kota Malang Tahun 2018. ${ }^{10}$ 
Jurnal Analisis Hukum

Volume 1, No. 2, September 2018
ISSN : 2620-4959 (online), 2620-3715 (print)

http://journal.undiknas.ac.id/index.php/JAH/index

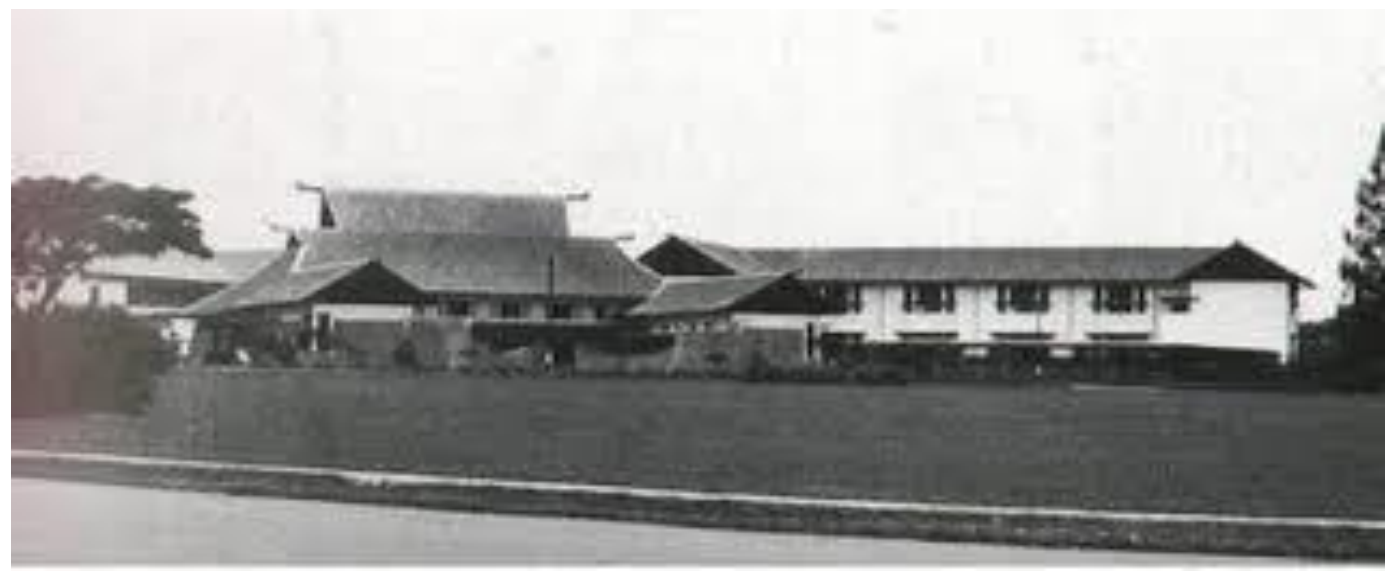

Gambar 3. Gedung SMA Negeri 1 pada waktu didirikan. ${ }^{11}$

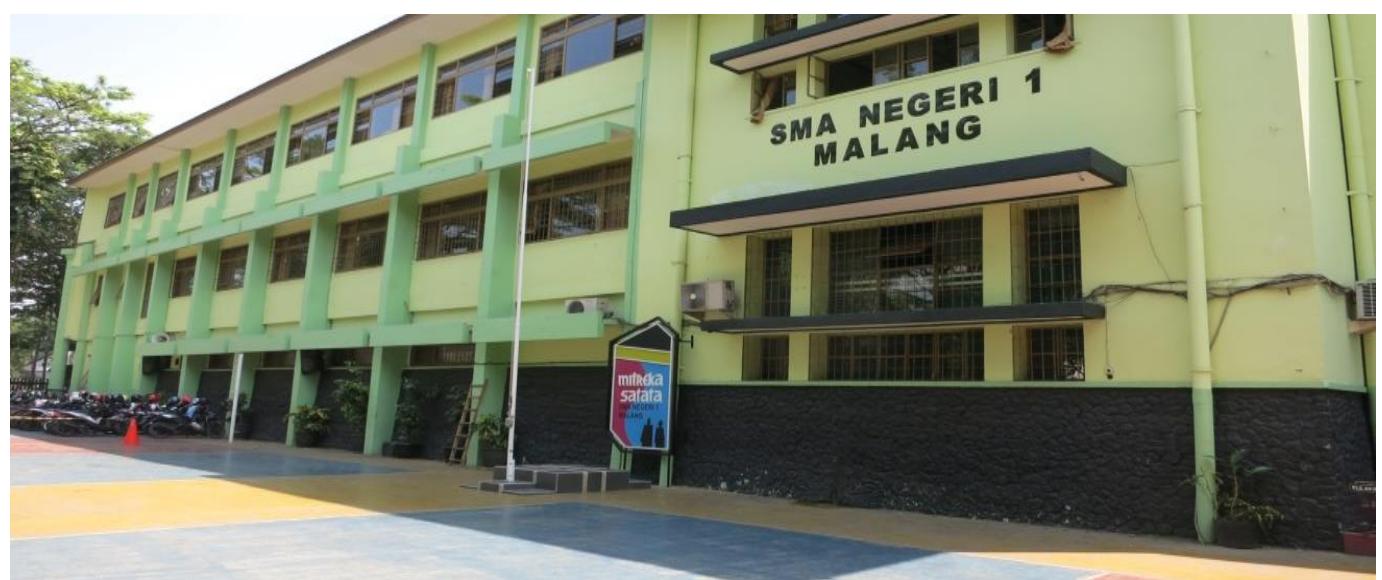

Gambar 4. Gedung SMA Negeri 1 pada tahun 2018. ${ }^{12}$

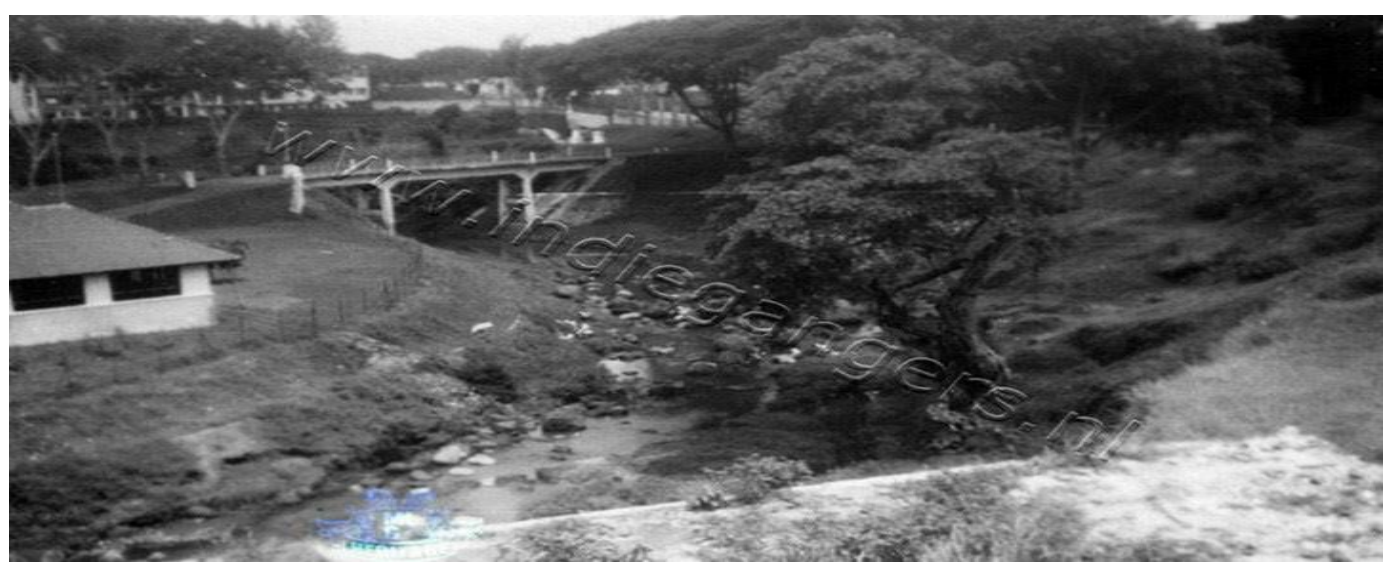

Gambar 5. Jembatan Splendid pada tahun 1930an. ${ }^{13}$

\section{${ }^{11}$ lbid}

${ }^{12}$ Survey lapangan 2018

${ }^{13}$ www.google. Opcit 


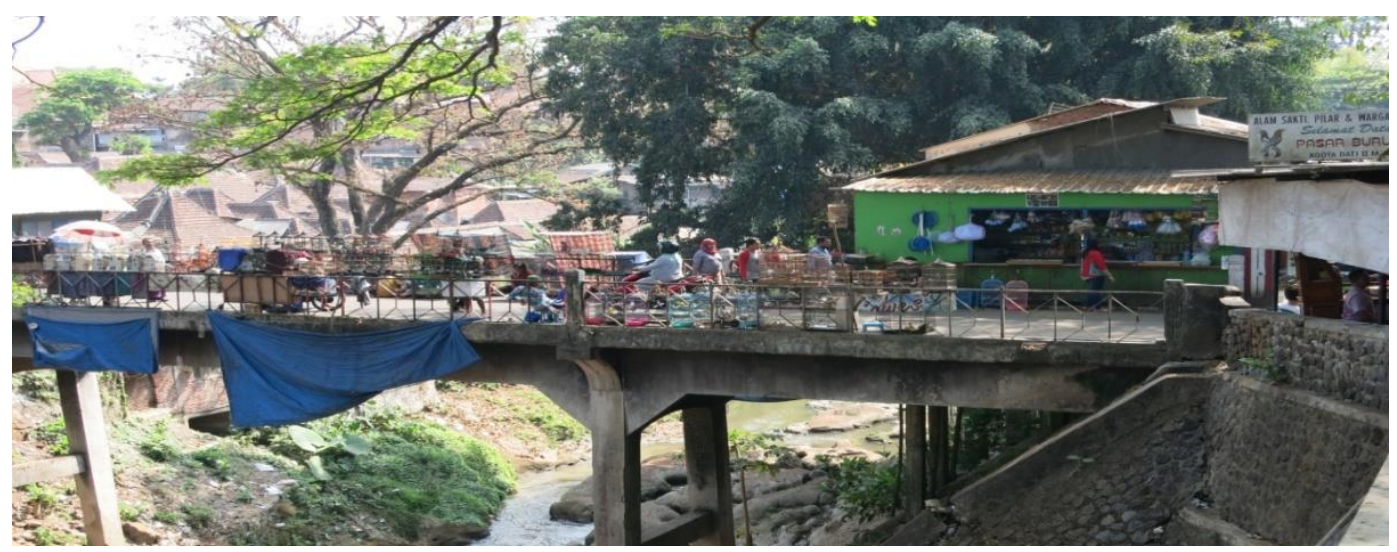

Gambar 6. Jembatan Splendid pada tahun 2018. ${ }^{14}$

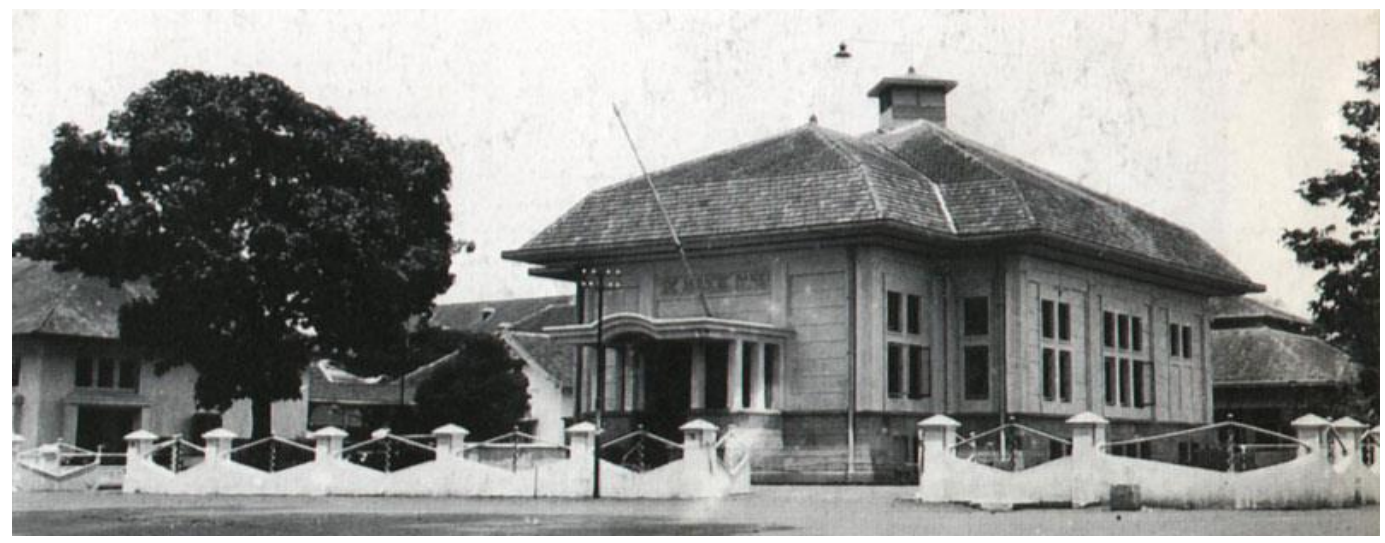

Gambar 7. Gedung Bank Indonesia pada jaman Belanda. ${ }^{15}$

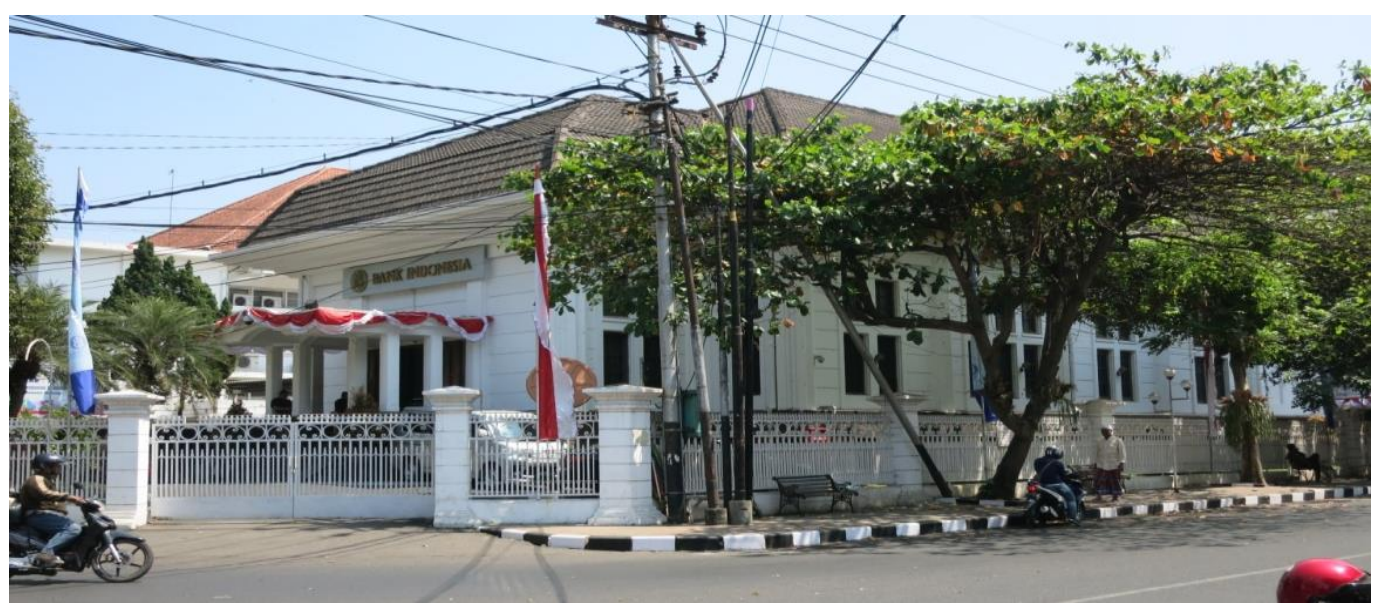

Gambar 8. Gedung Bank Indonesia pada tahun 2018. ${ }^{16}$

${ }^{14}$ Survey Op.cit

${ }^{15}$ www.google. Op.cit

${ }^{16}$ Survey Op.cit 


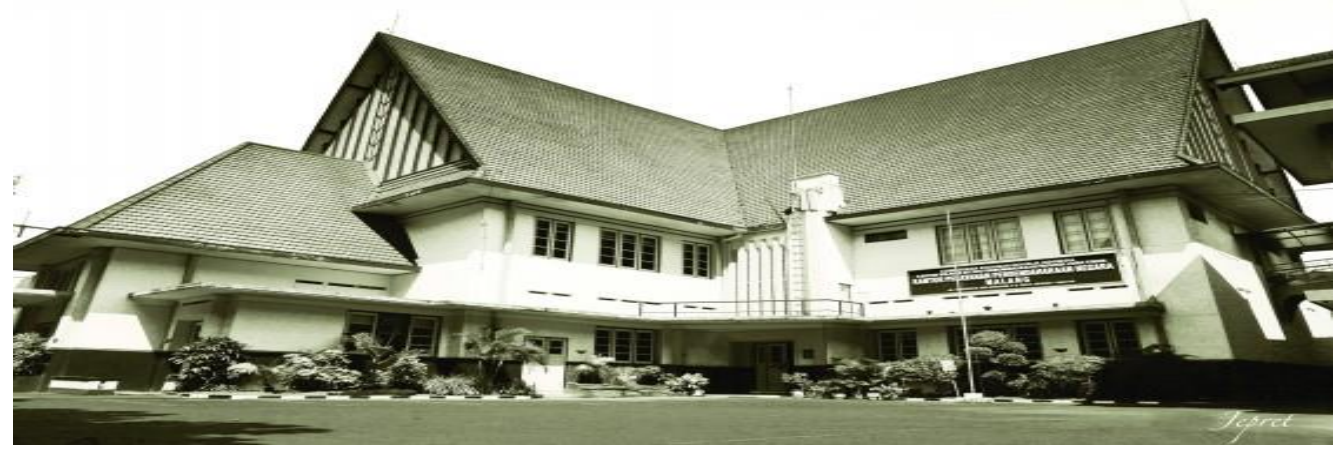

Gambar 9. Bangunan Kantor Pelayanan Perbendaharaan Negara (KPPN)

Kota Malang pada Jaman Belanda. ${ }^{17}$

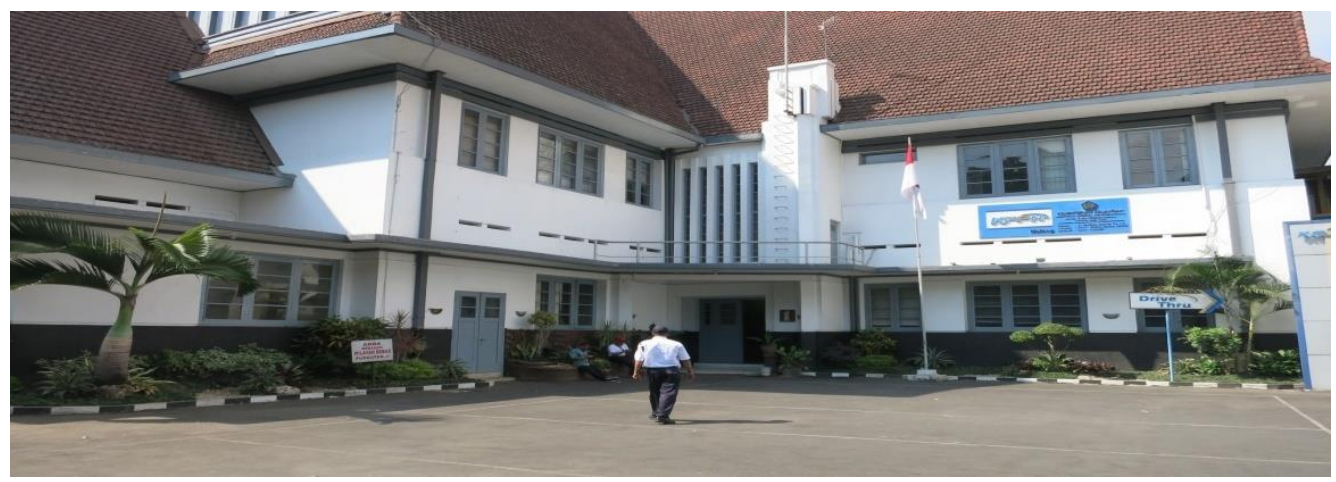

Gambar 10. Bangunan KPPN Kota Malang pada tahun $2018 .{ }^{18}$

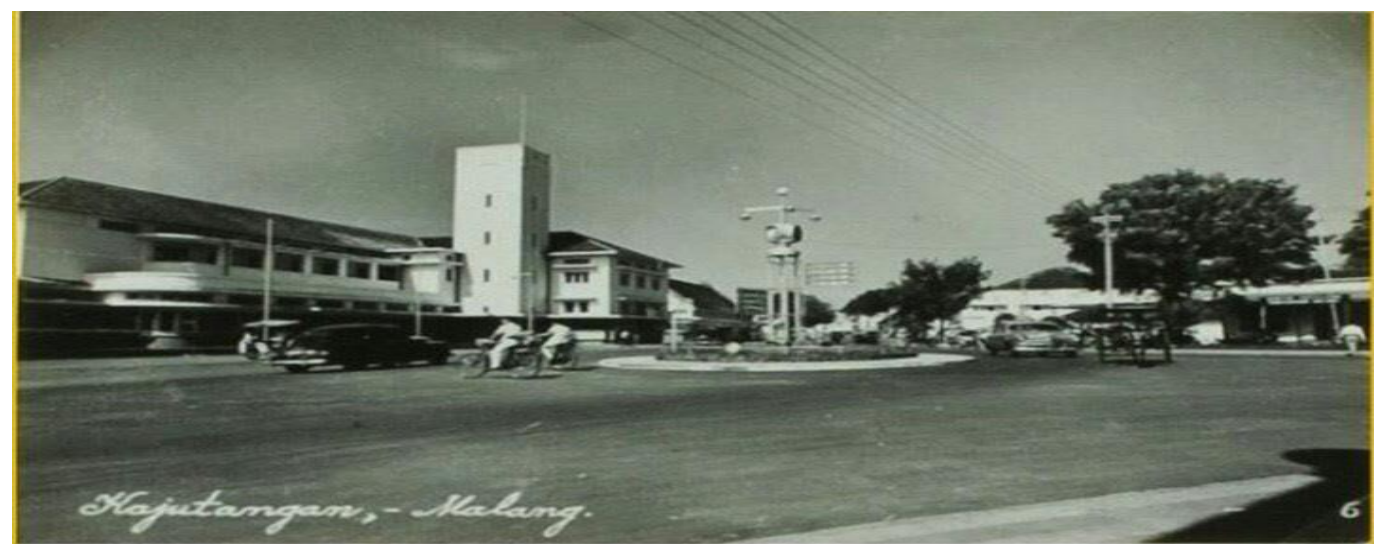

Gambar 11. Gedung PLN pada tahun $1948^{19}$

${ }^{17}$ www.google. Op.cit

${ }^{18}$ Survey Op.cit

${ }^{19}$ www.google. Op.cit 


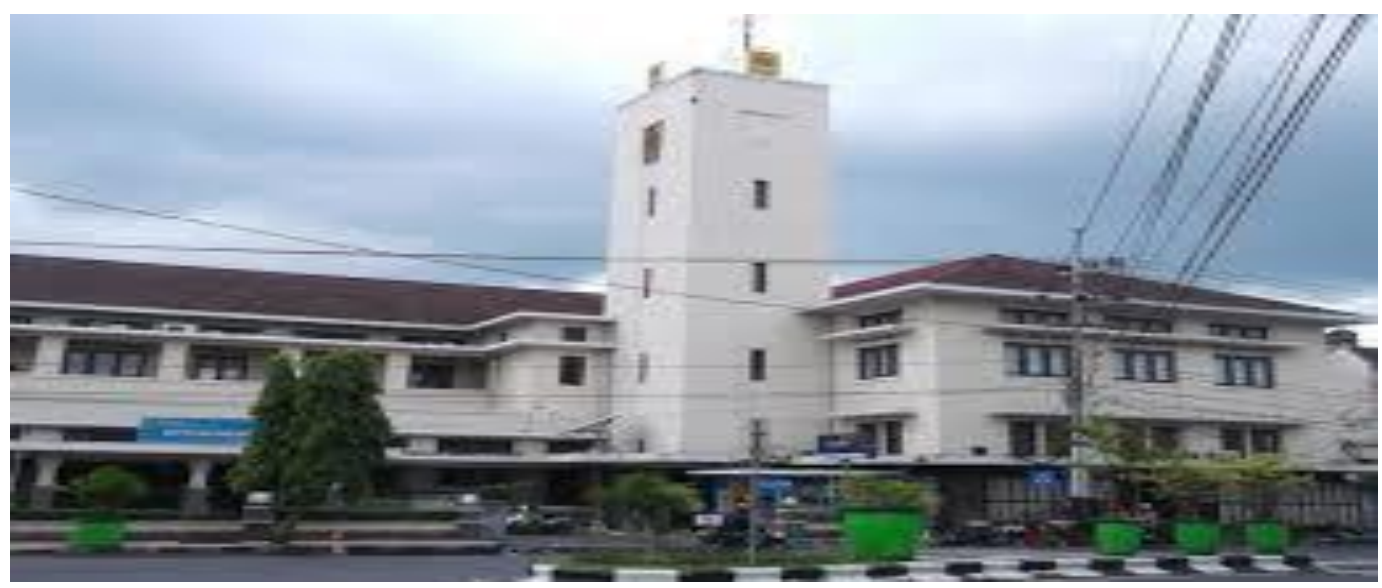

Gambar 12. Gedung PLN pada tahun 2018. ${ }^{20}$

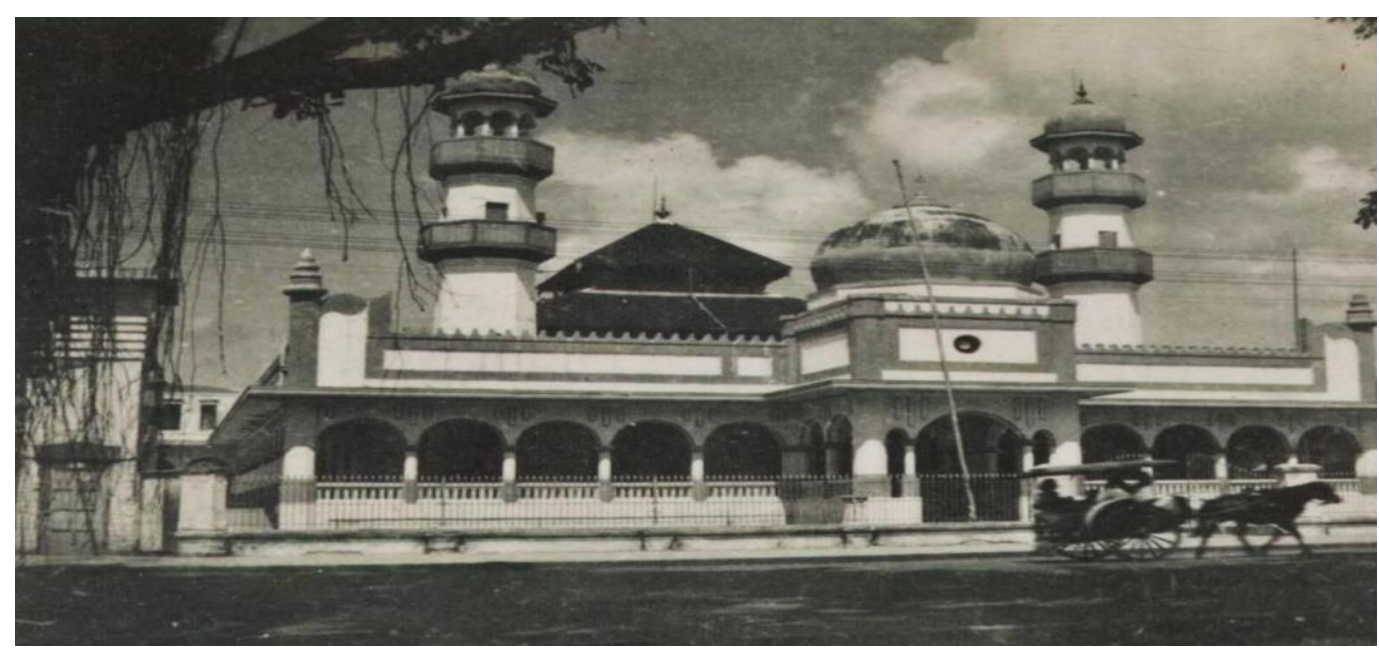

Gambar 13. Masjid Agung Jami pada jaman Belanda. ${ }^{21}$

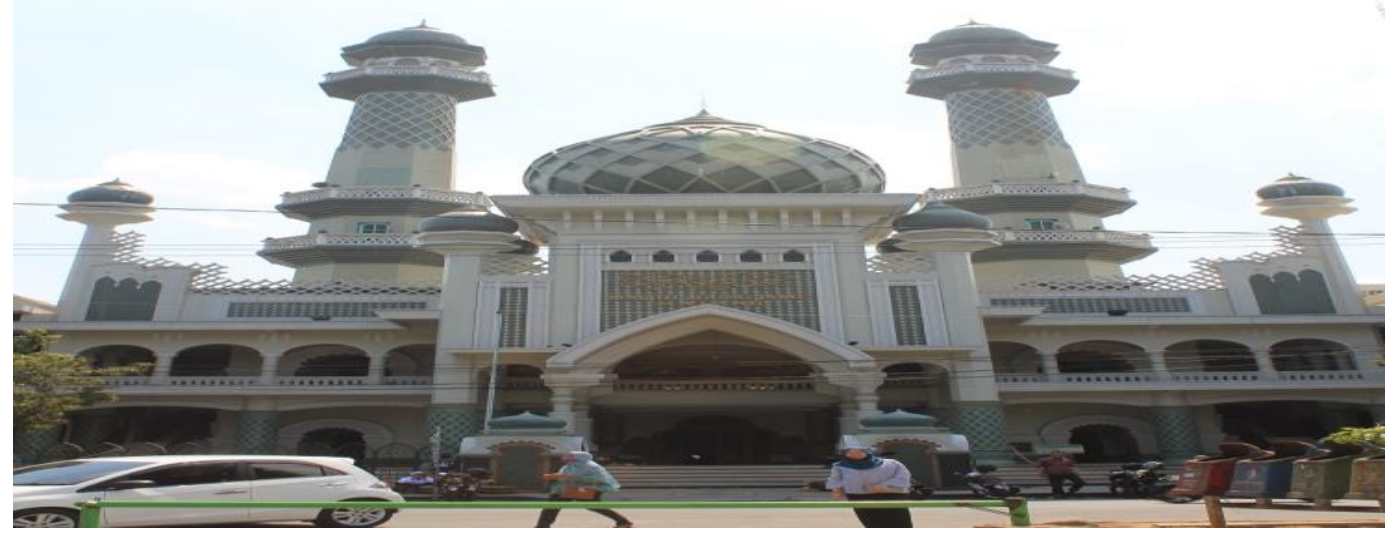

Gambar 14. Masjid Agung Jami pada tahun $2018 .^{22}$

${ }^{20}$ Survey Op.cit

${ }^{21}$ www.google. Op.cit 
Jurnal Analisis Hukum

Volume 1, No. 2, September 2018
ISSN : 2620-4959 (online), 2620-3715 (print)

http://journal.undiknas.ac.id/index.php/JAH/index

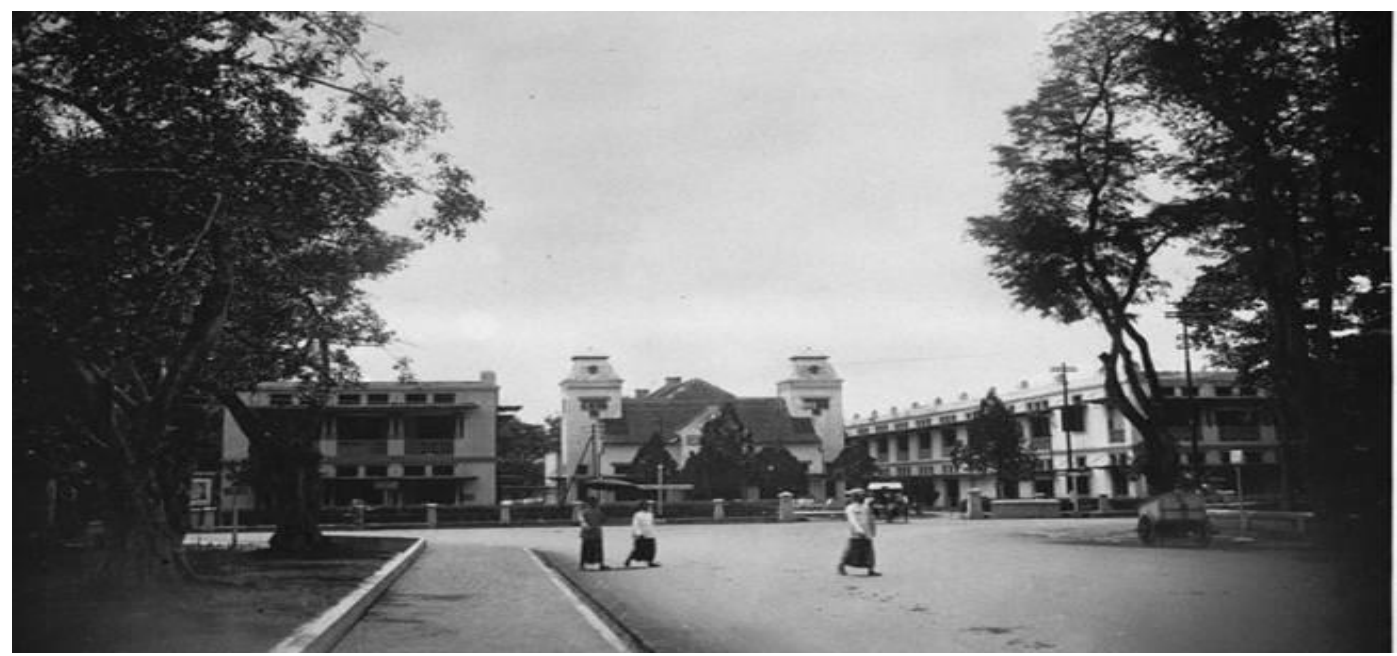

Gambar 15. Hotel Pelangi pada jaman Belanda. ${ }^{23}$

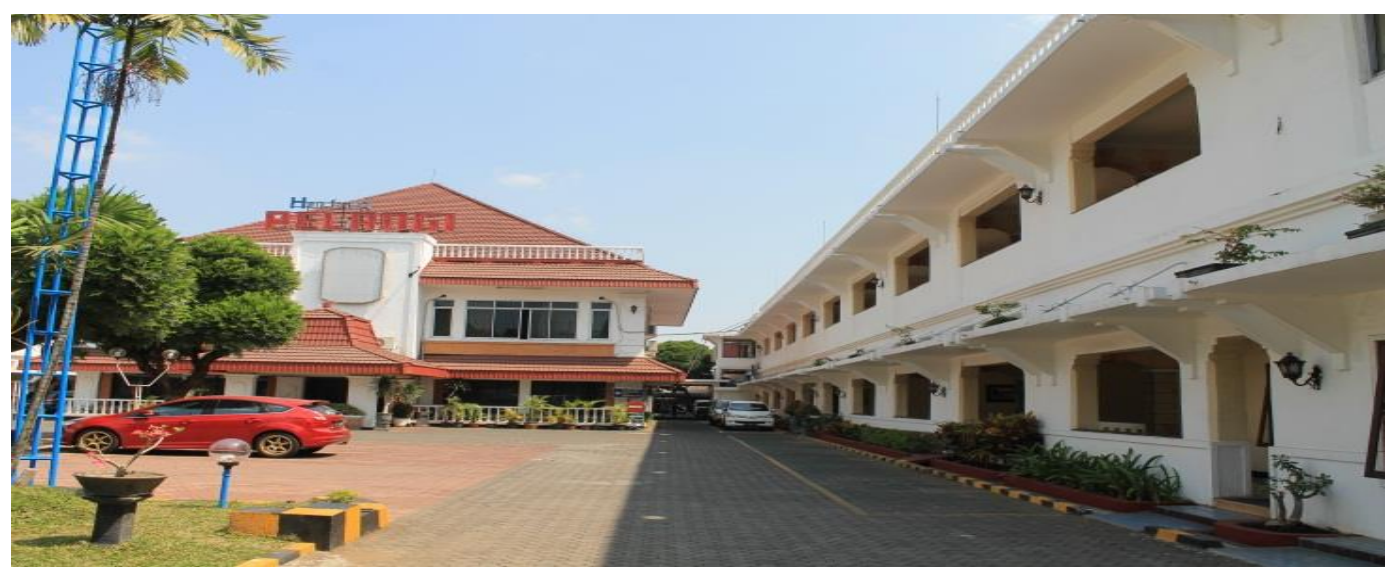

Gambar 16. Hotel Pelangi pada tahun 2018. ${ }^{24}$

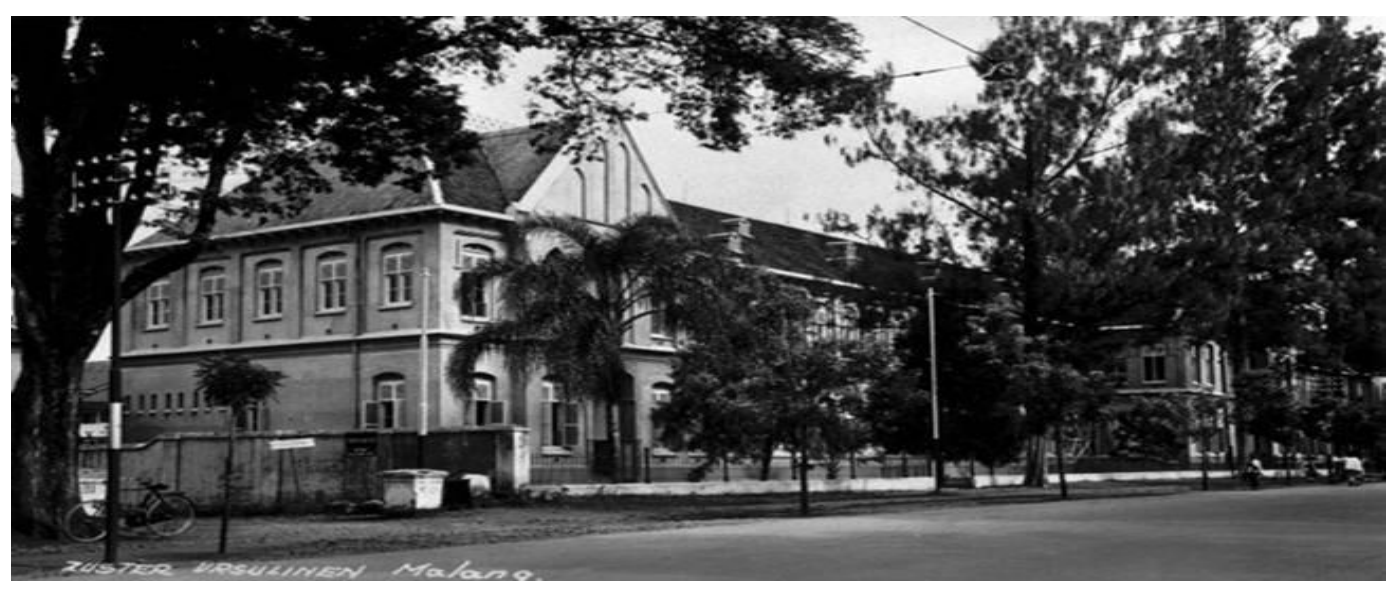

Gambar 17. Bangunan Cor Jesu pada jaman Belanda. ${ }^{25}$
${ }^{22}$ Survey Op.cit
${ }^{23}$ www.google. Op.cit
${ }^{24}$ Survey Op.cit 


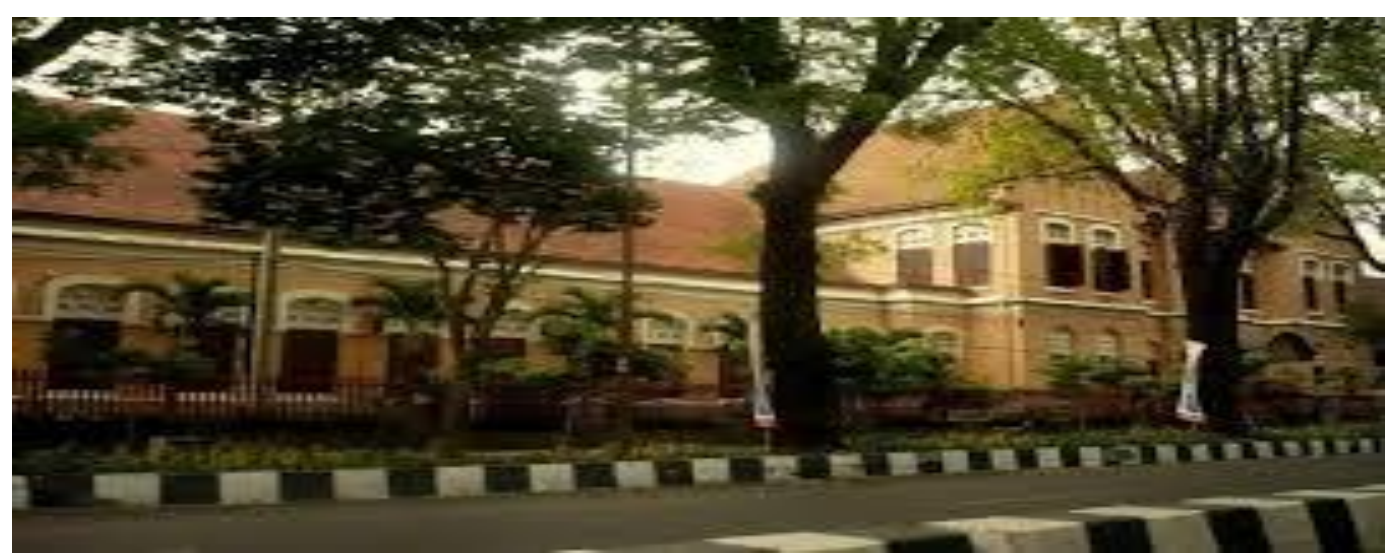

Gambar 18. Gedung Cor Jesu pada tahun 2018. ${ }^{26}$

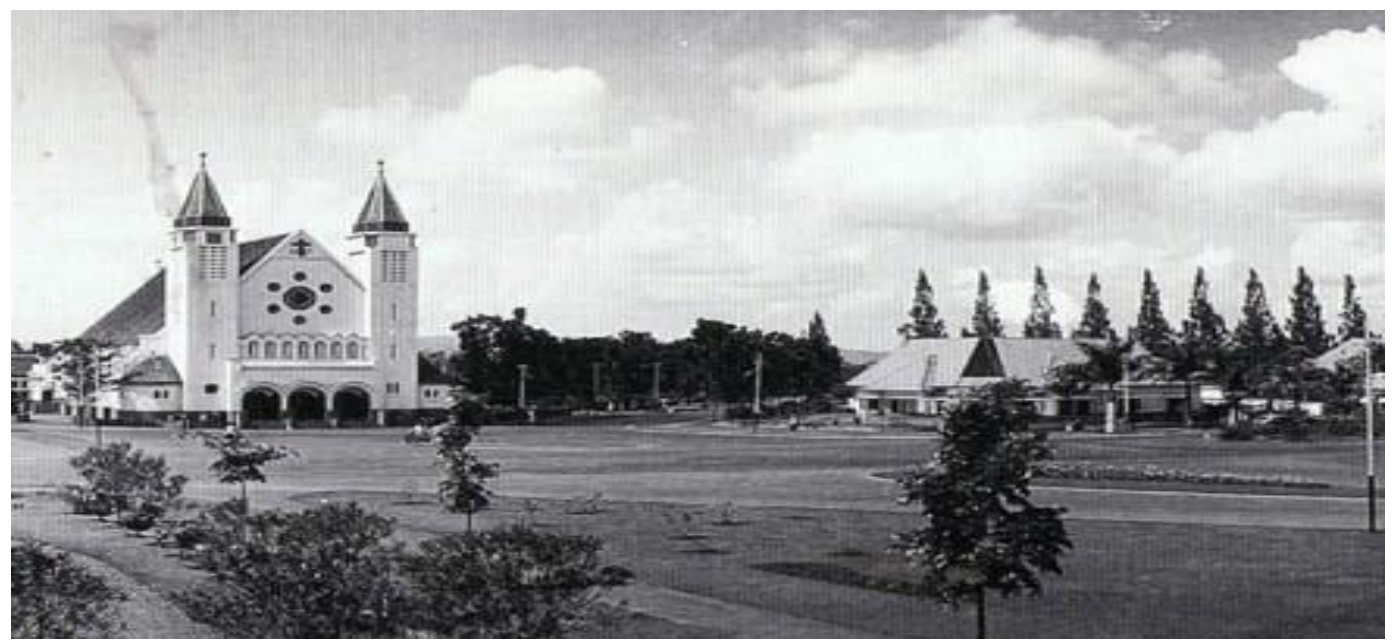

Gambar 19. Gereja ljen pada jaman Belanda. ${ }^{27}$

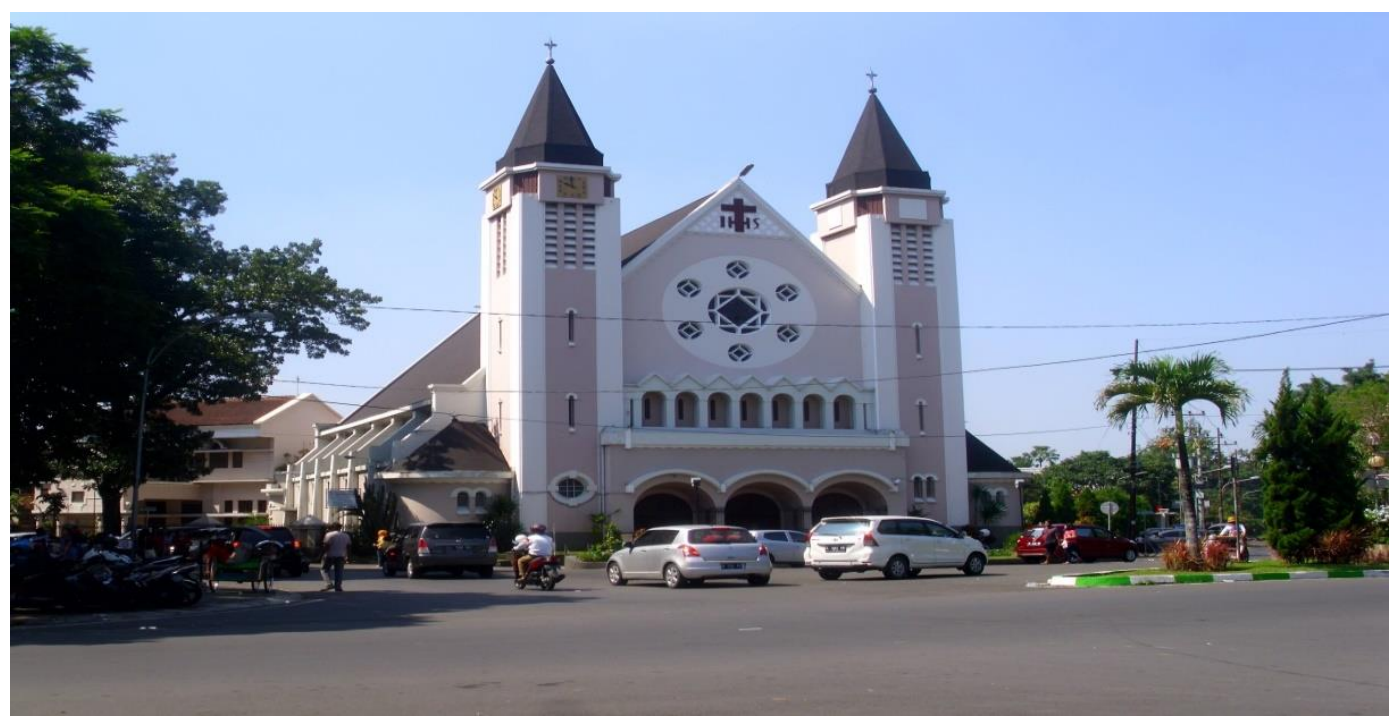

${ }^{25}$ www.google. Op.cit

${ }^{26} \mathrm{Ibid}$

${ }^{27} \mathrm{lbid}$ 
Gambar 20. Gereja Idjen pada tahun 2018.28
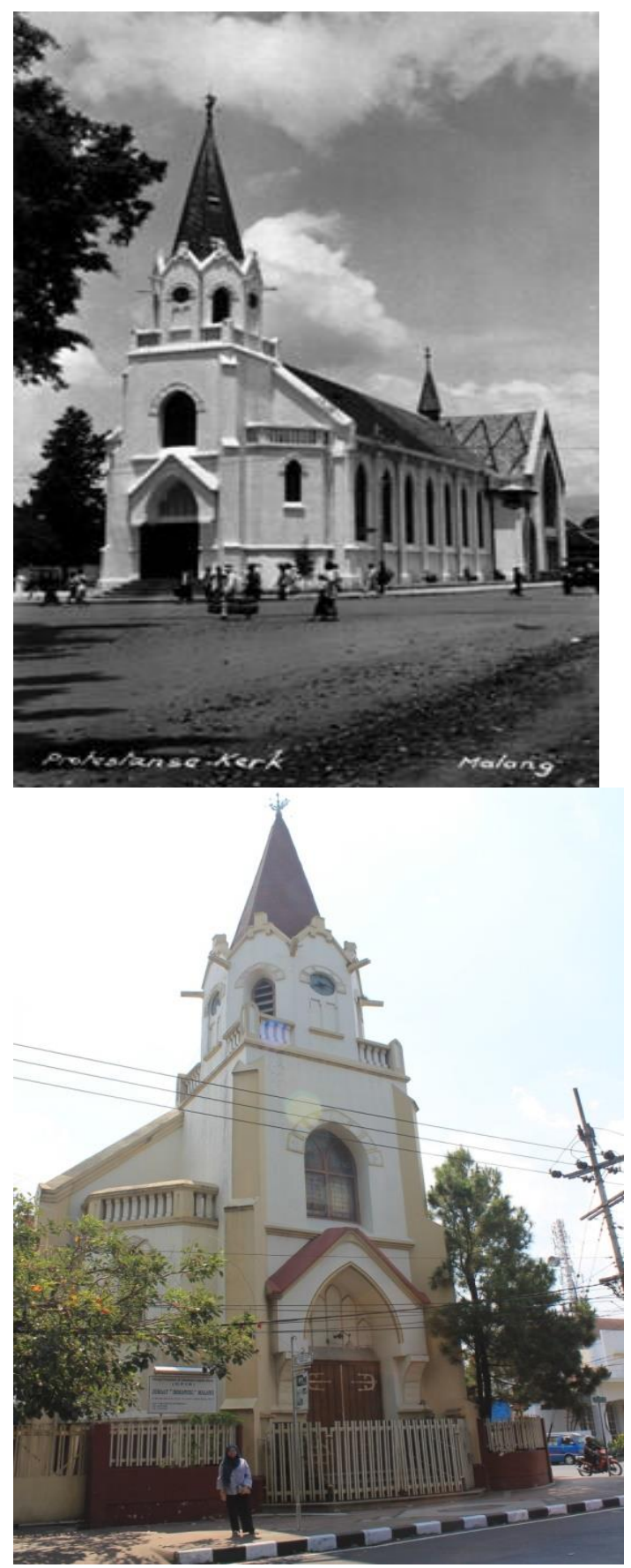

Gambar 21. GPIB Immanuel pada jaman Belanda (kiri) dan tahun 2018 $(\text { kanan })^{29}$

\section{${ }^{28}$ /bid}

${ }^{29}$ Gabungan www.google.co.id dan survey lapangan 2018 


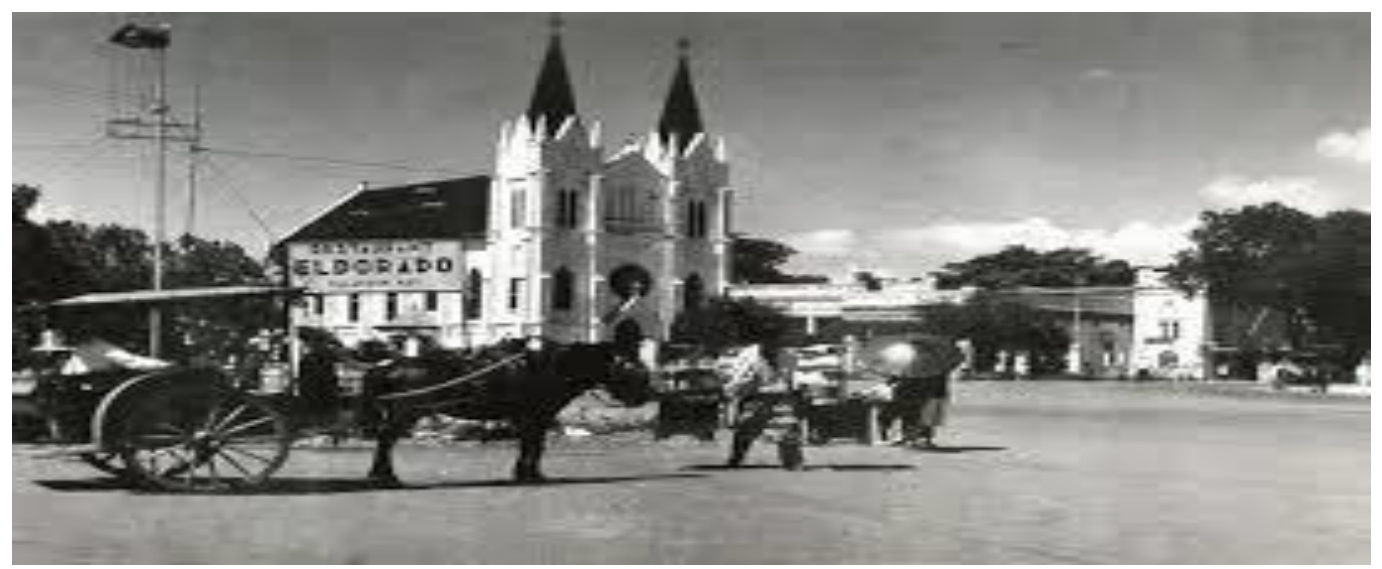

Gambar 22. Gereja Kayutangan pada tahun 1920.30

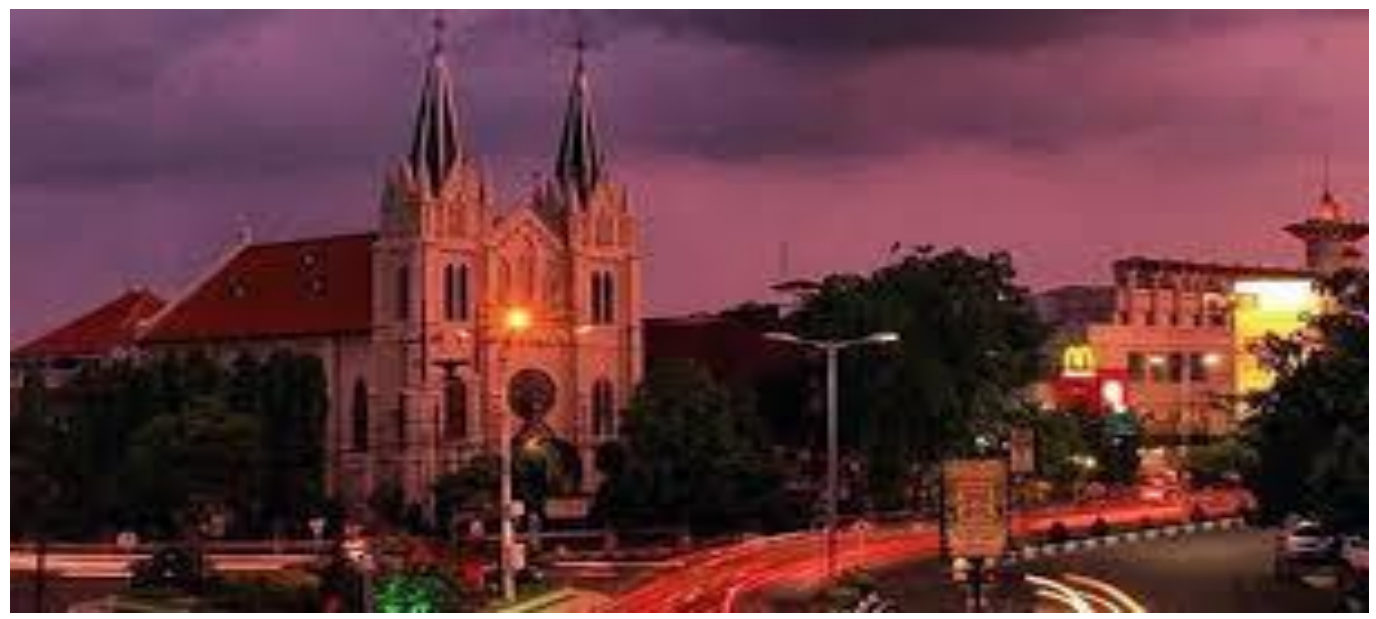

Gambar 23. Gereja Kayutangan tahun 2018. ${ }^{31}$

${ }^{30}$ www.google. Opcit

${ }^{31} \mathrm{ibid}$ 


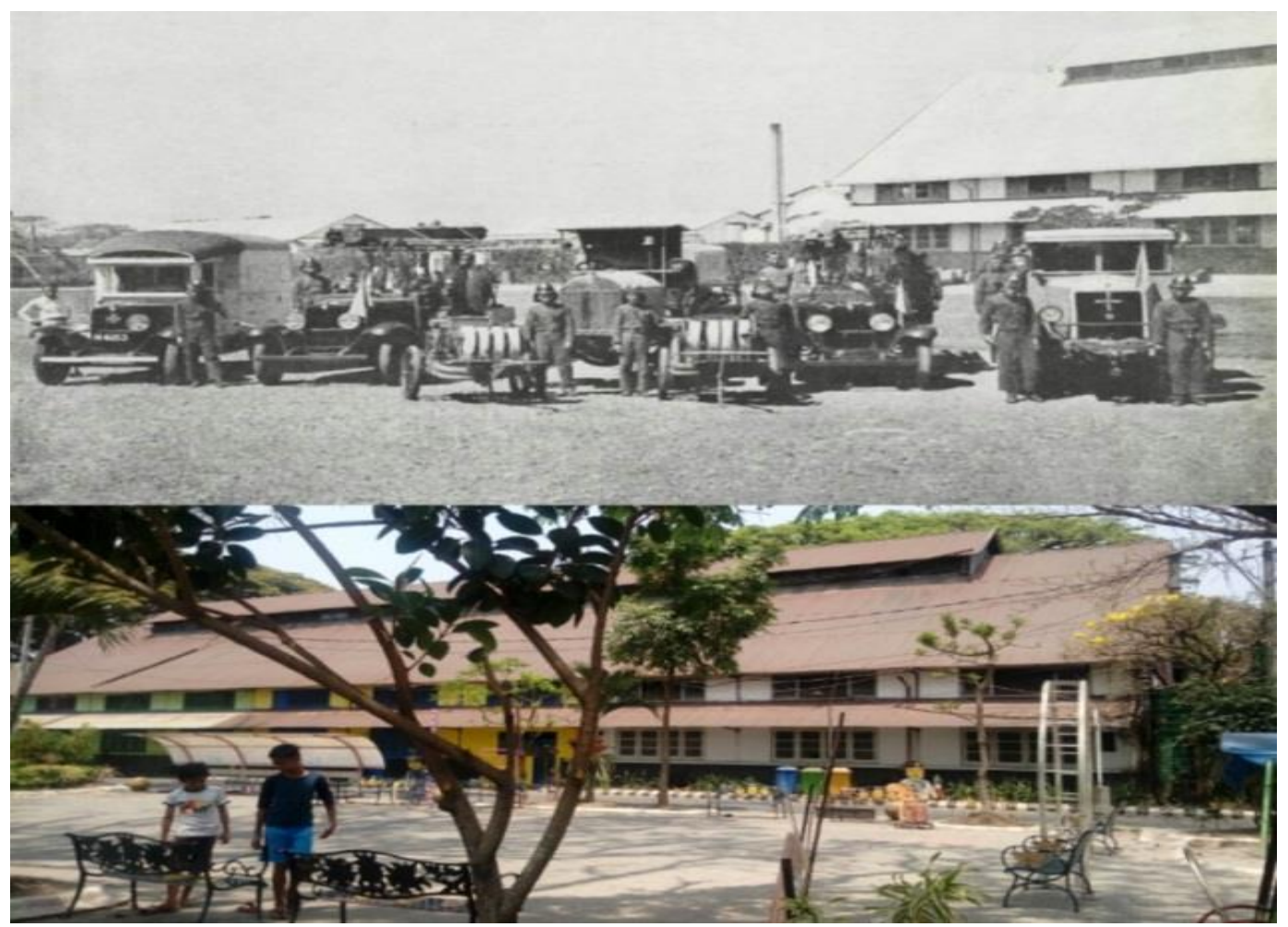

Gambar 24. Brandweer pada jaman Belanda (atas) dan pada tahun 2018 (bawah). ${ }^{32}$

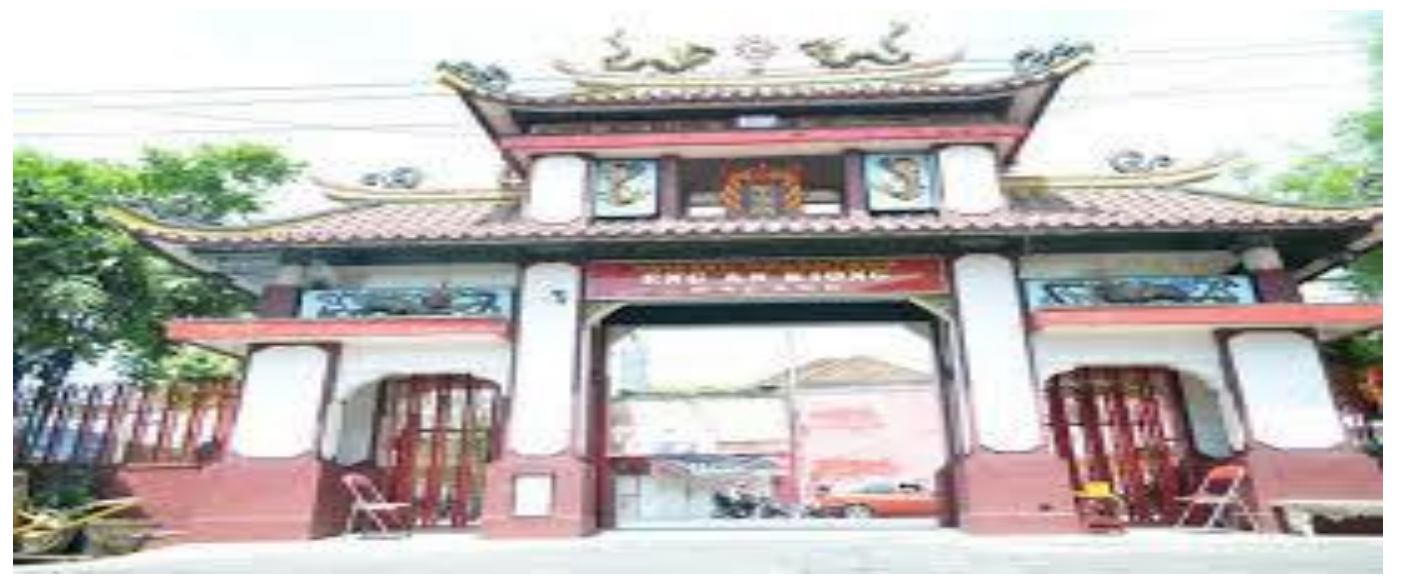

Gambar 25. Klenteng Eng An Kiong. ${ }^{33}$

${ }^{32}$ Gabungan Opcit

${ }^{33}$ www.google. Opcit 


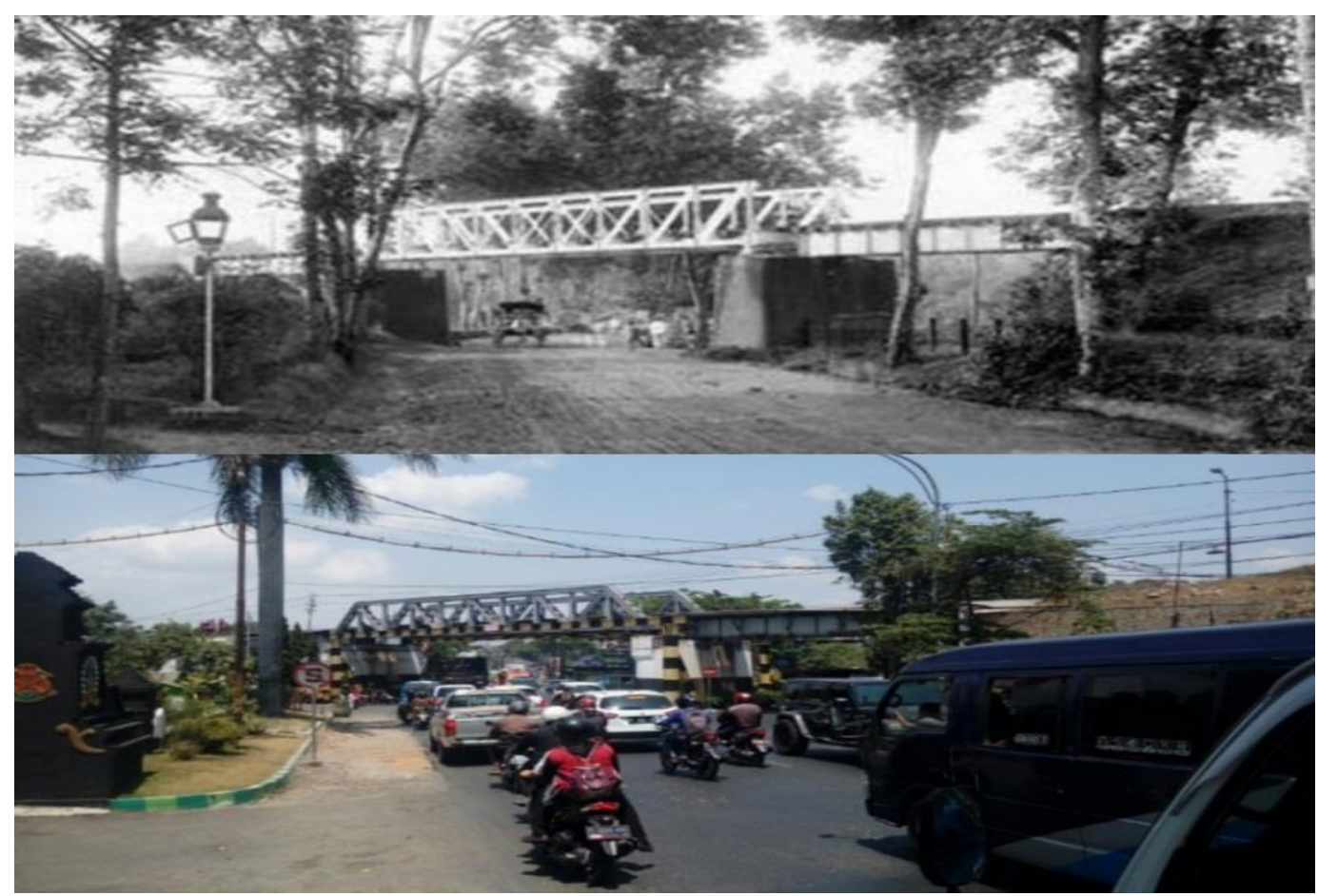

Gambar 26. Bug Gluduk pada jaman Belanda (atas) dan tahun 2018 (bawah) ${ }^{34}$

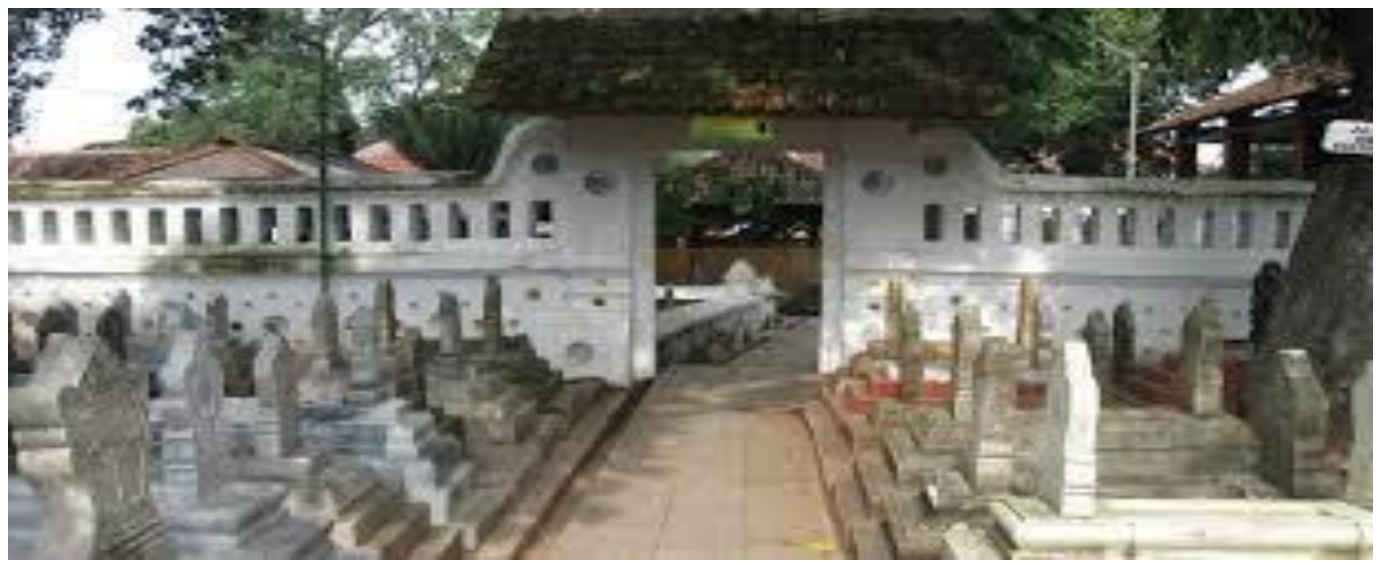

Gambar 27. Komplek makam Ki Ageng Gribig. ${ }^{35}$

${ }^{34}$ Gabungan. Opcit

${ }^{35}$ www.google. Opcit 


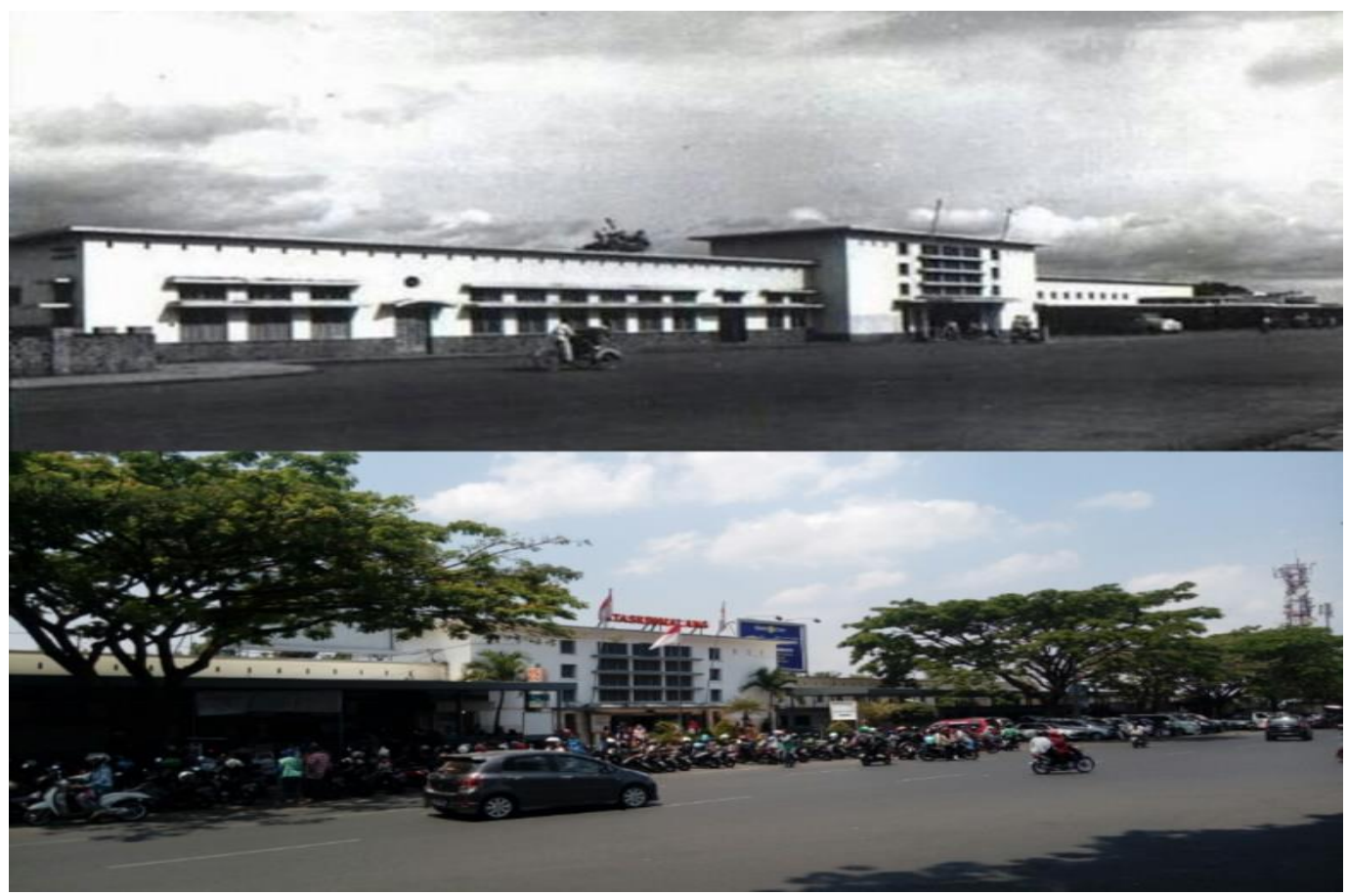

Gambar 28. Stasiun Kota Baru pada jaman Belanda (atas) dan tahun 2018 (bawah) $)^{36}$

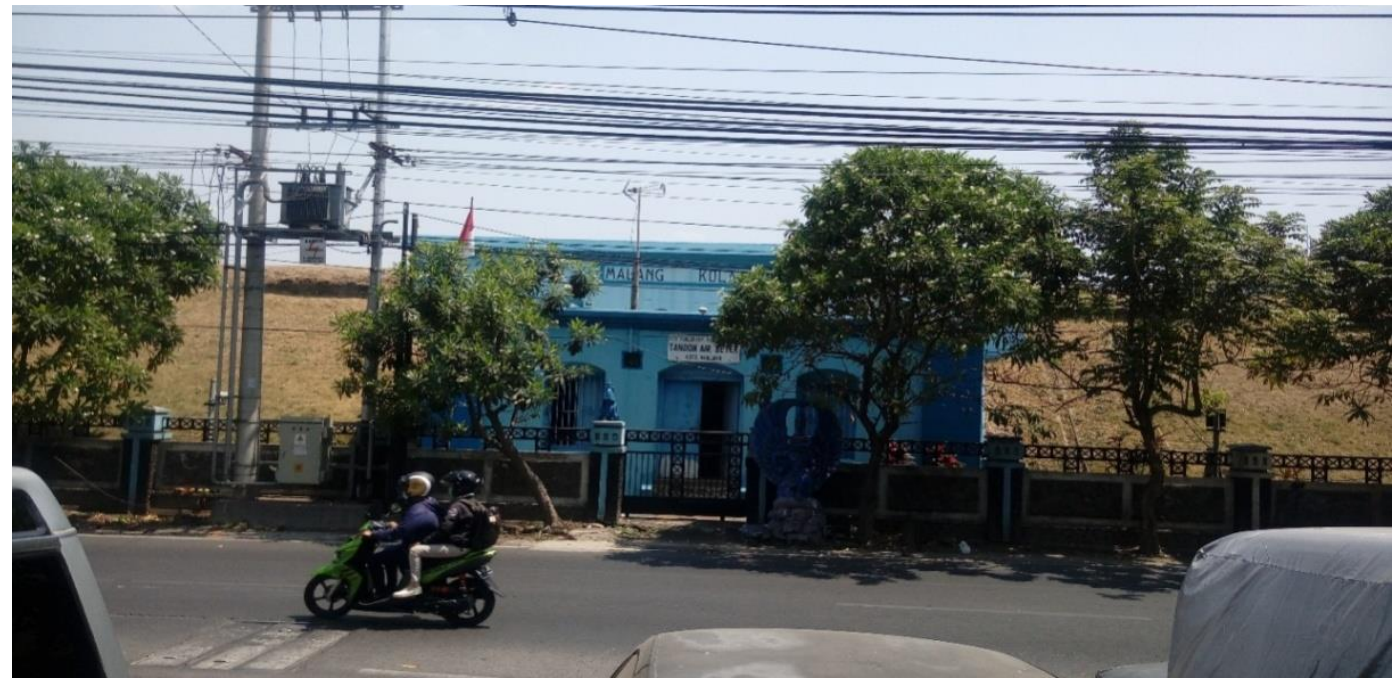

Gambar 29. Tandon Air Betek. ${ }^{37}$

${ }^{36}$ Gabungan. Op.cit

${ }^{37}$ Survey. Op.cit 


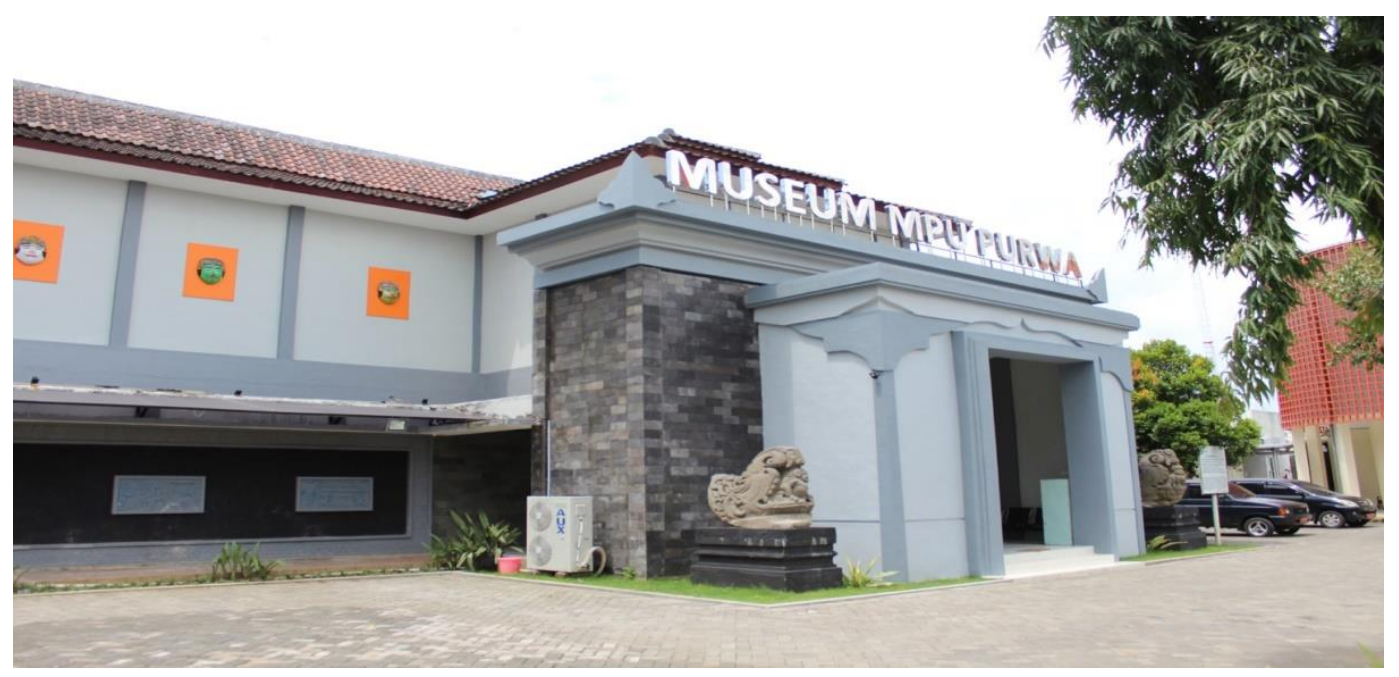

Gambar 30. Museum Mpu Purwo pada tahun 2018. ${ }^{38}$

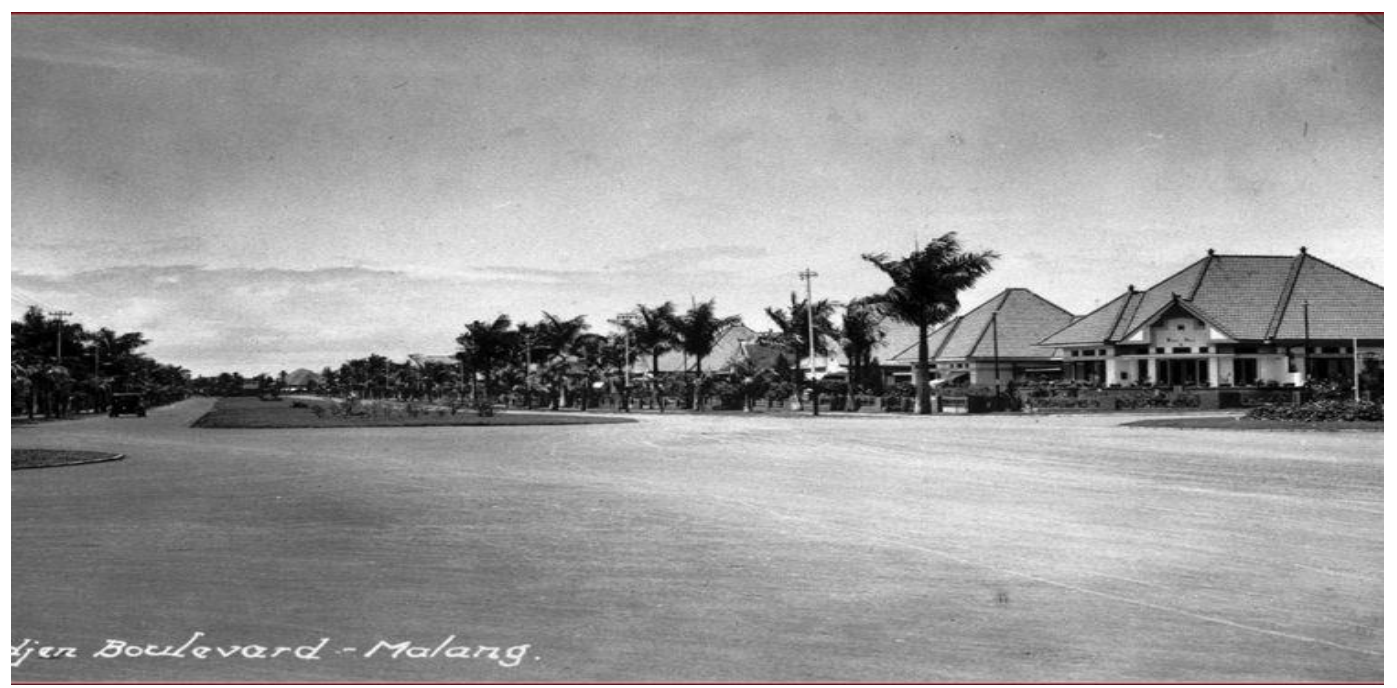

Gambar 31. Ijen Boulevard pada jaman Belanda. ${ }^{39}$

${ }^{38}$ www.google. Op.cit

${ }^{39}$ ibid 


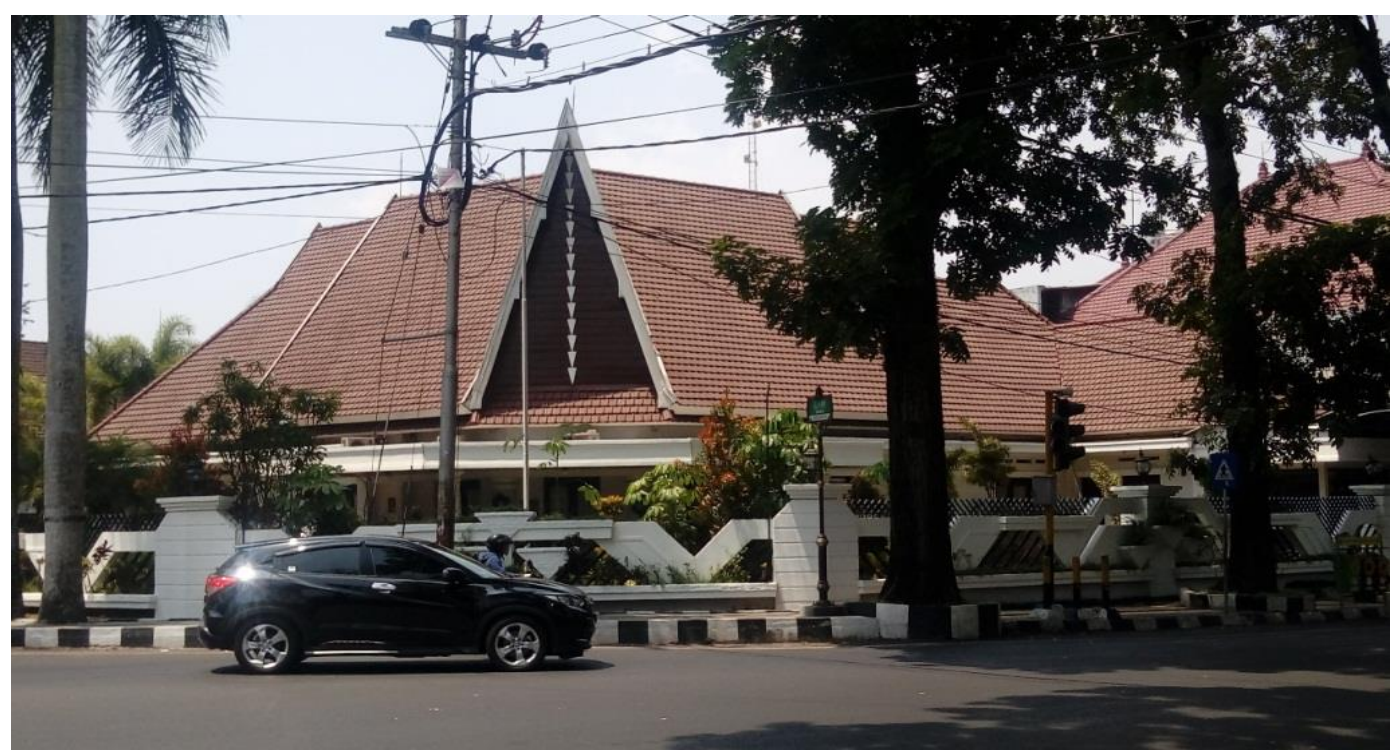

Gambar 32. Rumah Dinas Walikota Malang pada tahun $2018^{40}$

Preservasi adalah kegiatan yang berhubungan secara tidak langsung terhadap pemeliharaan artifak(peninggalan budaya) pada kondisi fisik yang sama seperti ketika diterima oleh kurator. Tampilan estetiknya tidak boleh ada yang ditambah atau dikurangi. Intervensi apapun yang perlu untuk mengandakan „preserve hanya boleh pada permukaan atau pada „kulit saja serta tidak mencolok. Sedangkan konservasi adalah kegiatan yang berhubungan dengan intervensi fisik terhadap bahan atau elemen bangunan (bersejarah) yang ada untuk meyakinkan kesinambungan integritas secara struktural. Tingkatan kegiatan konservasi dapat berkisar dari penanganan kecilsampai penanganan besar. ${ }^{41}$

Kegiatan preservasi dan konservasi pada bangunan lama bernilai sejarah dapat dikemas dan diwadahi dalam bingkai kawasan kota lama bernilai sejarah. Perhatian yang tinggi dari pihak Pemerintah Kota terhadap kegiatan ini pada dasarnya adalah bentuk apresiasi terhadap: (a) nilai arsitektural pada bangunan lama, (b) nilai sejarah dan budaya pada sejarah kota, (c) nilai pendidikan (edukasi) pada generasi mendatang dan (e) penghargaan akan kegiatan pariwisata dan rekreasi dalam kawasan kota. ${ }^{42}$

${ }^{40}$ Survey. Opcit

${ }^{41}$ Pawitro, Udjianto, 2015, Preservasi-Konservasi Bangunan Bersejarah Dan Pengelolaan Kawasan Kota Lama, Simposium Nasional RAPI XIV-2015 FT UMS ISSN 1412-9612, h.A16

${ }^{42}$ ibid 
Pemerintah Kota Malang telah berusaha melakukan upaya-upaya penting terkait dengan kegiatan pelestarian dan pemeliharaan terhadap bangunan dan lingkungan bersejarah yang menjadi perhatian masyarakat terutama bagi para perencanaan kota, urban designer, arsitek/ perancang bangunan dan arkeolog yang menaruh minat didalamnya. Upaya tersebut berupa: (1) Preservasi, (2) Konservasi, (3) Restorasi, (4) Rekonstruksi, (5) Rekonstitusi, (6) Adaptive ReUsed, (7) Rehabilitasi, dan (8) Replikasi. Kesemua istilah-istilah ini pada pokoknya sangat berguina bagi upaya pelestarian, pemeliharaan dan mempertahankan sesuatu benda atau objek bernilai sejarah serta upaya perawatannya guna dapat berlangsung lama digunakan oleh kalangan masyarakat luas

Preservasi dan Konservasi adalah upaya untuk memelihara suatu tempat sedemikian rupa sehingga makna budaya dari tempat tersebut dapat dipertahankan. Berdasarkan The Burra Charter, ${ }^{43}$ upaya konservasi memiliki 4 (empat) hal utama, antara lain: a) Pelestarian, yaitu upaya pengelolaan pusaka untuk memperpanjang usia benda cagar budaya, situs atau kawasan peninggalan bersejarah dengan cara perlindungan, pemeliharaan, pemanfaatan dan atau pengembangan untuk menjaga keberlanjutan, keserasian dan daya dukungnya dalam menjawab dinamika jaman untuk membangun kehidupan yang berkualitas. b) Perlindungan, yaitu upaya mencegah dan menanggulangi segala gejala atau akibat kerusakan benda, situs dan kawasan cagar budaya baik dikarenakan manusia atau alam dengan cara: (1) Penyelamatan, yaitu pencegahan dan penanggulangan ancaman kerusakan atau kemusnahan perlindungan benda, situs, dan kawasan cagar budaya yang timbul baik oleh alam atau manusia secara teknis; (2) Pengamanan, yaitu perlindungan dengan cara menjaga, mencegah dan menanggulangi hal-hal yang dapat merusak benda, situs, dan kawasan cagar budaya. c) Pemeliharaan, yaitu upaya pelestarian benda, situs dan kawasan cagar budaya baik dikarenakan manusia atau alam dengan cara: (1) Pemugaran, yaitu dengan cara mempertahankan keaslian berdasarkan data yang ada dan bila diperlukan dilakukan perkuatan struktur yang dapat dipertanggungjawabkan dari segi arkeologis, historis dan teknis; (2) Pemanfaatan, yaitu pemberdayaan

${ }^{43}$ Burra Charter, 2003, Pedoman dan Prinsip-prinsip Preservasi dan Konserrvasi Bangunan dan Lingkungan Bersejarah-Burra Charter, World Harritage Council UNESCO Publisher, Paris. 
benda, situs dan kawasan cagar budaya sebagai aset budaya untuk berbagai kepentingan yang tidak bertentangan dengan prinsip pelestarian. d) Pengelolaan, yaitu upaya pelestarian dan pemanfaatan benda, situs dan kawasan cagar budaya melalui kebijakan pengaturan perencanaan, perlindungan, pemeliharaan, pemugaran, pemanfaatan, dan pengendalian.

Pemerintah Kota Malang juga melakukan pembekalan materi tentang bangunan yang akan dikonservasi. Seperti kapan bangunan didirikan, apa gaya arsitektur yang digunakan, pada masa apa bangunan tersebut dibuat, dan informasi tersebut didapat melalui literatur. a) Survey teknis untuk mengumpulkan data kerusakan pada bangunan dan informasi lainnya yang diperlukan. Pada tahap ini diperlukan kegiatan dokumentasi sebagai media penyimpanan informasi. b) Analisis terhadap bangunan dengan data yang telah terkumpul dokumentasi bentuk dan denah asli berdasarkan analisis forensik, periode dan gaya arsitektur pada bangunan sebagai penunjuk zaman, metodologi konstruksi yang digunakan pada zaman tersebut, dan penyebab kerusakan pada bangunan. c) Proposal solusi yang merupakan hasil dari proses analisa berupa implementasi konservasi yang dijadikan dokumen lelang. Di dalamnya berisi panduan konservasi untuk bangunan tersebut dan posisi kerusakan dan apa saja yang perlu diperbaiki secara detail.

Banyaknya bentuk kegiatan preservasi dan konservasi, berupa restorasi dan revitalisasi akan cocok diaplikasikan pada bangunan cagarbudaya yang ada di Malang. Restorasi untuk mengembalikan keadaan bangunan yang rusak menjadi baik kembali dan direvitalisasi atau dimanfaatkan kembali agar bangunan cagar budaya tersebut tidak hilang.

Proses revitalisasi sebuah kawasan atau bagian kota mencakup perbaikan aspek fisik dan aspek ekonomi dari bangunan maupun ruang kota. Revitalisasi aspek fisik merupakan strategi jangka pendek yang dimaksudkan untuk mendorong terjadinya peningkatan kegiatan ekonomi jangka panjang. Revitalisasi aspek fisik diyakini dapat meningkatkan kondisi fisik (termasuk juga ruang ruang publik) kota, namun tidak untuk jangka panjang. Untuk itu, tetap diperlukan perbaikan dan peningkatan aktivitas ekonomi (economic revitalization) yang merujuk kepada aspek sosial budaya serta aspek lingkungan (environmental objectives). Hal tersebut mutlak diperlukan karena melalui pemanfaatan yang produktif, 
diharapkan akan terbentuk sebuah mekanisme perawatan dan kontrol yang langgeng terhadap keberadaan fasilitas dan infrastruktur kota.

Uraian tentang nilai-nilai penting dari benda, situs, kawasan cagar budaya menurut Aylin Orbasli dalam buku "Architectural Conservation"44: a) Age and Rarity Value, nilai yang terkait di periode kapan bangunan tersebut dibangun, bila tidak ada gambar atau foto atau dokumen tertulis lainnya dapat dilihat dari fisik bangunan dan kelangkaan yang dilihat dari tipe bangunan, dan teknologi bangunan. b) Architectural Value, terkait kualitas desain dan kontribusi terhadap lingkungan binaan, langgam desain yang diterapkan, karya dari arsitek yang dianggap baik, atau sebagai pelopor penggunaan suatu teknologi bangunan. c) Artistic Value, terkait kualitas karya seni, misalnya lukisan mural. d) Associative Value, e) Cultural Value, memiliki informasi mengenai banyak aspek dari masa lampau, mulai dari penggunaa material, kerajinan tangan, teknik konstruksi yang mempunyai peran penting pada tradisi dan budaya. f) Economic Value, keuntungan ekonomi bangunan bersejarah terutama melalui pariwisata. g) Educational Value,apa yang bisa dipelajari dari bangunan bersejarah, misalnya periode sejarah, kehidupan, hubungan sosial, dan teknik konstruksi di masa lampau. h) Emotional Value, terkait ikatan emosi yang terjadi antara manusia dengan bangunan sebagai rasa kagum dan hormat terhadap desain dan karya seni. i) Historic Value, bukti fisik tentang masa lampau, yang juga memiliki peran penting dalan sejarah atau bangunan yang terhubung dengan periode tertentu dalam sejarah. j) Landscape Value, monumen, bangunan atau tata kota atau tata kawasan saling melengkapi. k) Local Distinctiveness, bangunan heritage yang berkontribusi yang menjadi ciri khas, dengan keunikannya yang tidak didapat di tempat lain misalnya dari material atau teknologi atau karakter bangunan. I) Political Value. m) Public value, ruang publik yang menjadi tempat demonstrasi, unjuk rasa, atau revolusi. n) Religious and Spiritual Value, dimana menjadi tempat peziarahan, misalnya gereja, masjid, candi, gunung, sungai, dan lain sebagainya. o) Scientific, Research and Knowledge Value, dilihat dari teknologi bangunan yang diterapkan, material yang dipakai, darimana

${ }^{44}$ Finke,Alice Louise, 2008, Implementing Preventive ArchitecturalConservation: Do Historic Property Stewards inthe United States Possess the Tool to Meet theChallenge?University of Pennsylvania, Pannsylvania 
material didatangkan, peralatan apa saja yang dipakai, penyebab kerusakan. p) Social value, sebagai bagian dari pertukaran sosial atau hubungan sosial, misalnya taman. q) Symbolic value, sebagai simbol peristiwa bersejarah, misalnya monumen, Triumph, Tembok Berlin.r) Technical value, teknologi yang dipakai dalam konstruksi suatu bangunan dan kontribusinya terhadap teknologi bangunan di masa mendatang.

Pelaksanaan konservasi revitalisasiakan disesuaikan dengan kondisi bangunan tua tersebut. Sebelum melakukan konservasi, sebaiknya melakukan identifikasi pada bangunan tua tersebut sebagai bahan pertimbangan. Aspek-aspek tersebut kemudian diuraikan berdasarkan komponen yang akan diatur dalam konservasi revitalisasi. Setelah ituakan dirumuskan dasar peraturan dan penetapan sasaran yang akan dicapai dalam konservasi revitalisasi.

\section{Kesimpulan}

Berdasarkan hasil penelitian diatas, dapat disimpulkan bahwa yang dilakukan pemerintah kota Malang saat ini adalah secara law in books menuangkan dalam Perda Kota Malang Nomor 1 tahun 2018 tentang Cagar Budaya, dimana di dalamnya tercantum beberapa usaha yang dapat dilakukan untuk mempertahankan bangunan peninggalan sejarah, antara lain: (1) Pemanfaatan yaitu pendayagunaan Cagar Budaya untuk kepentingan sebesar-besarnya kesejahteraan rakyat dengan tetap mempertahankan kelestariannya; (2) Revitalisasi yaitu kegiatan pengembangan yang ditujukan untuk menumbuhkan kembali nilai-nilai penting Cagar Budaya dengan penyesuaian fungsi ruang baru yang tidak bertentangan dengan prinsip pelestarian dan nilai budaya masyarakat; dan (3) Adaptasi yaitu upaya pengembangan Cagar Budaya untuk kegiatan yang lebih sesuai dengan kebutuhan masa kini dengan melakukan perubahan terbatas yang tidak akan mengakibatkan kemerosotan nilai pentingnya atau kerusakan pada bagian yang mempunyai nilai penting. Sedangkan secara law in action, Pemerintah Kota Malang selama ini melaksanakan renovasi terhadap dua puluh bangunan tersebut tanpa mengubah (alih fungsi) bangunan yang bersangkutan. 


\section{DAFTAR PUSTAKA}

\section{Buku:}

Finke, Alice Louise, 2008, Implementing Preventive Architectural Conservation: Do Historic Property Stewards in the United States Possess the Tool to Meet the Challenge? University of Pennsylvania, Pannsylvania

Koentjaraningrat,2012, Pengantar IImu Antropologi, Radar Jaya Offset, Jakarta.

Lindsey, Tim, Eddy Damian, Simon Butt, Tomi Suryo Utomo, 2006, Hak Kekayaan Intelektual Suatu Pengantar, PT Alumni, Bandung.

Pawitro, Udjianto, 2015, Preservasi-Konservasi Bangunan Bersejarah Dan Pengelolaan Kawasan Kota Lama, Simposium Nasional RAPI XIV2015 FT UMS ISSN 1412-9612.

Soemitro, Ronny Hanitijo, 1988, Metodologi Penelitian Hukum dan Jurimetri, Ghalia Indonesia, Jakarta.

\section{Peraturan Perundang-Undangan:}

Undang-Undang Nomor 11 Tahun 2010 tentang Cagar Budaya Undang-Undang Nomor 28 Tahun 2014 tentang Hak Cipta

Peraturan Gubernur Jawa Timur Nomor 66 Tahun 2015 Tentang Pelestarian Cagar Budaya Provinsi Jawa Timur

Perda Kota Malang Nomor 1 Tahun 2018 Tentang Cagar Budaya

\section{Artikel dan Jurnal:}

Burra Charter, 2003, Pedoman dan Prinsip-prinsip Preservasi dan Konserrvasi Bangunan dan Lingkungan Bersejarah-Burra Charter, World Harritage Council UNESCO Publisher, Paris.

Sardjono, Agus, 2007, Bagaimana Melindungi Kekayaan Warisan Budaya Sebagai Kekayaan Intelektual Bangsa. Melalui makalahnya pada seminar Pekan Produk Budaya Indonesia.

UNESCO, 1987, dalam "Convention Concerning the Protection of the World Cultural and Natural Heritage". 